Provided for non-commercial research and educational use only. Not for reproduction or distribution or commercial use.

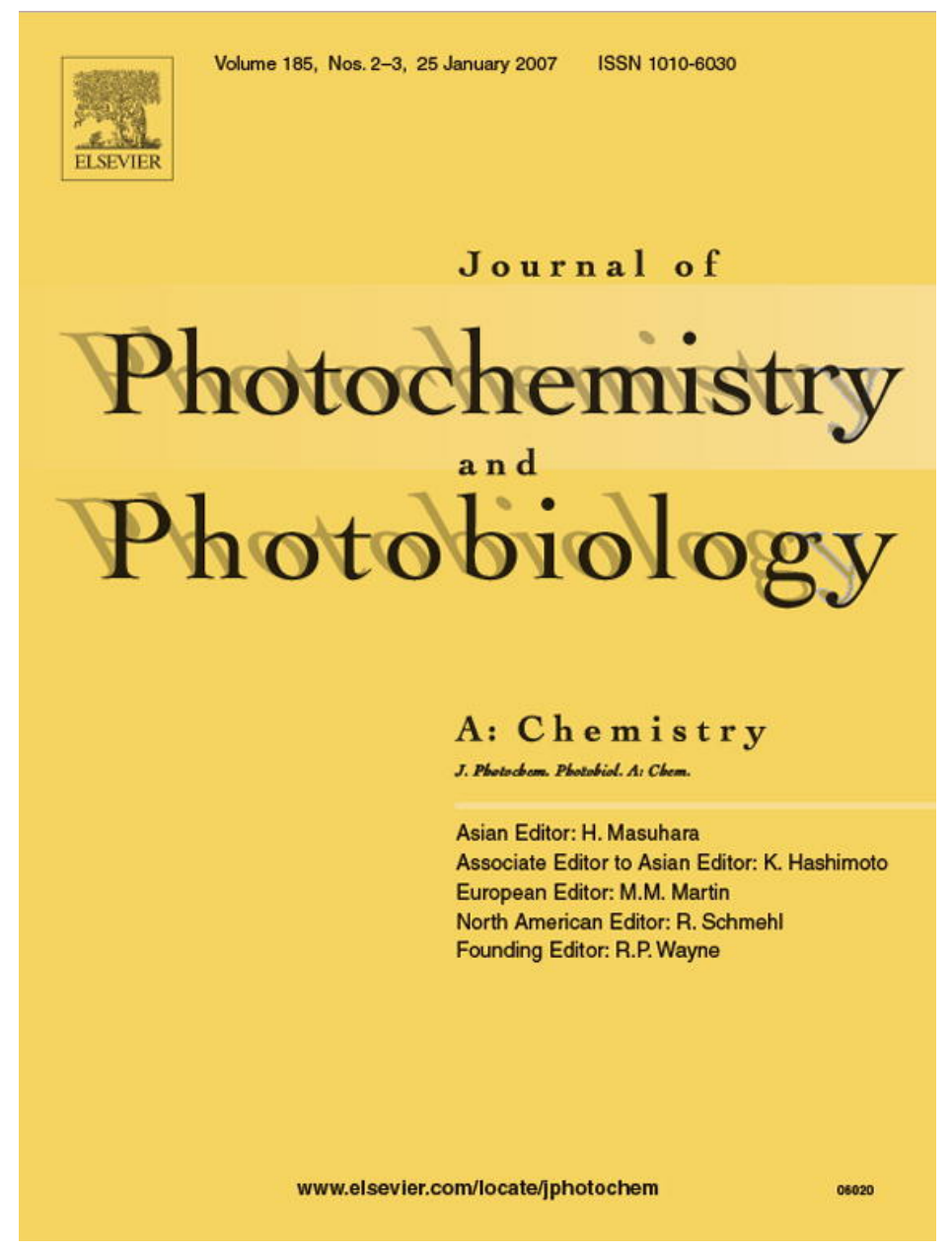

This article was originally published in a journal published by Elsevier, and the attached copy is provided by Elsevier for the author's benefit and for the benefit of the author's institution, for non-commercial research and educational use including without limitation use in instruction at your institution, sending it to specific colleagues that you know, and providing a copy to your institution's administrator.

All other uses, reproduction and distribution, including without limitation commercial reprints, selling or licensing copies or access,

or posting on open internet sites, your personal or institution's website or repository, are prohibited. For exceptions, permission may be sought for such use through Elsevier's permissions site at: 


\title{
A mechanism for the photochemical transformation of nitrate in snow
}

\author{
Hans-Werner Jacobi* , Birgit Hilker \\ Alfred Wegener Institute for Polar and Marine Research, Am Handelshafen 12, 27570 Bremerhaven, Germany \\ Received 1 June 2006; received in revised form 29 June 2006; accepted 30 June 2006 \\ Available online 8 July 2006
}

\begin{abstract}
Photochemical reactions of trace compounds in snow have important implications for the composition of the atmospheric boundary layer in snow-covered regions and for the interpretation of concentration profiles in snow and ice regarding the composition of the past atmosphere. One of the prominent reactions is the photolysis of nitrate, which leads to the formation of $\mathrm{OH}$ radicals in the snow and to the release of reactive nitrogen compounds, like nitrogen oxides ( $\mathrm{NO}$ and $\mathrm{NO}_{2}$ ) and nitrous acid ( $\mathrm{HONO}$ ) to the atmosphere. We performed photolysis experiments using artificial snow, containing variable initial concentrations of nitrate and nitrite, to investigate the reaction mechanism responsible for the formation of the reactive nitrogen compounds. Increasing the initial nitrite concentrations resulted in the formation of significant amounts of nitrate in the snow. A possible precursor of nitrate is $\mathrm{NO}_{2}$, which can be transformed into nitrate either by the attack of a hydroxy radical or the hydrolysis of the dimer $\left(\mathrm{N}_{2} \mathrm{O}_{4}\right)$. A mechanism for the transformation of the nitrogen-containing compounds in snow was developed, assuming that all reactions took place in a quasi-liquid layer (QLL) at the surface of the ice crystals. The unknown photolysis rates of nitrate and nitrite and the rates of NO and $\mathrm{NO}_{2}$ transfer from the snow to the gas phase, respectively, were adjusted to give an optimum fit of the calculated time series of nitrate, nitrite, and gas phase $\mathrm{NO}_{x}$ with respect to the experimental data. Best agreement was obtained with a $\sim 25$ times faster photolysis rate of nitrite compared to nitrate. The formation of $\mathrm{NO}_{2}$ is probably the dominant channel for the nitrate photolysis. We used the reaction mechanism further to investigate the release of $\mathrm{NO}_{x}$ and $\mathrm{HONO}$ under natural conditions. We found that $\mathrm{NO}_{x}$ emissions are by far dominated by the release of $\mathrm{NO}_{2}$. The release of HONO to the gas phase depends on the $\mathrm{pH}$ of the snow and the HONO transfer rate to the gas phase. However, due to the small amounts of nitrite produced under natural conditions, the formation of HONO in the QLL is probably negligible. We suggest that observed emissions of $\mathrm{HONO}$ from the surface snow are dominated by the heterogeneous formation of $\mathrm{HONO}$ in the firn air. The reaction of $\mathrm{NO}_{2}$ on the surfaces of the ice crystals is the most likely HONO source to the gas phase.
\end{abstract}

(C) 2006 Elsevier B.V. All rights reserved.

Keywords: Photochemical reactions; Snow; Nitrate; Nitrite; Nitrogen oxides

\section{Introduction}

Photochemical reactions leading to the chemical transformation of trace compounds in the atmosphere do not only occur in the atmospheric gas and liquid phases, but also in the tropospheric ice phase. Such reactions can take place in the upper layers of the natural snow-covers in polar and alpine regions [1]. The photolysis of nitrate $\left(\mathrm{NO}_{3}{ }^{-}\right)$was first identified as an important photochemical reaction in this environment [2]. This reaction is considered as one of the key reactions in surface-snow and has been the subject of a series of field [2-17] and laboratory studies [18-27]. Nitrate photoly-

\footnotetext{
* Corresponding author. Tel.: +49 4714831 1493; fax: +49 47148311425.

E-mail address: hwjacobi@awi-bremerhaven.de (H.-W. Jacobi).
}

sis has an impact on the composition of and processes in the surface-snow. It also affects the atmosphere after the release of volatile and reactive nitrogen compounds to the gas phase [28,29].

Nitrate is one of the dominating anions found in snow samples in both polar regions [30]. However, the photochemical processing can alter the concentrations in the snow after deposition. Significant losses of nitrate from the surface snow at polar sites with very low snow accumulation rates were attributed to the $\mathrm{NO}_{3}{ }^{-}$photolysis [24,31]. This effect influences the interpretation of $\mathrm{NO}_{3}{ }^{-}$profiles in firn and ice cores, which can convolute information obtained about levels of reactive nitrogen compounds in the atmosphere in the past [32]. In addition, $\mathrm{NO}_{3}{ }^{-}$photolysis can affect further trace compounds in the snow. Laboratory experiments have shown that it leads to the formation of highly reactive hydroxyl $(\mathrm{OH})$ radicals in the snow 
[22] in agreement with well-known aqueous phase processes [33]. The generated $\mathrm{OH}$ has the potential to attack organic compounds, eventually leading to the formation of oxidized hydrocarbons like formaldehyde, acetaldehyde, and acetone $[1,34,35]$.

Evidence of the formation of more volatile compounds, which are quickly released to the gas phase, is supported by several field and laboratory studies. Emissions of nitrogen oxides $\left(\mathrm{NO}_{x}=\mathrm{NO}+\mathrm{NO}_{2}\right)$ from the surface snow under the influence of solar radiation have been reported from several Arctic [2,4,11,12], Antarctic [5-7,15], as well as a mid-latitude sites [3]. Nitrous acid (HONO) has also been found to be released from the surface snow at non-marine polar sites $[8,11,16]$, although HONO fluxes from alkaline snow seem to be negligible or even directed to the snow $[17,36]$. These emissions are driven by the strongly enhanced concentrations of the reactive nitrogen compounds in the interstitial air of the surface snow compared to ambient concentrations $[9,14,16]$. They have a strong effect on photochemical processes occurring in the atmospheric boundary layer above snow-covered regions. $\mathrm{NO}_{x}$ mixing ratios affected by emissions from the snowpack can reach values on the order of several hundreds of $\mathrm{pptV}$ (parts per trillion by volume) under stable atmospheric conditions, even in remote polar regions $[7,11,15]$. In addition, HONO concentrations up to 70 pptv have been reported for polar regions $[8,9,16,17,37]$. However, the applied collecting techniques using mist chambers or aqueous scrubbers are prone to interferences for example by pernitric acid $\left(\mathrm{HO}_{2} \mathrm{NO}_{2}\right)$, raising concerns about the actual HONO concentrations in polar regions [16,28,38]. Recently, Liao [38] reported simultaneous HONO measurements at South Pole station using laser-induced fluorescence (LIF) and mist chamber-ion chromatography (MC-IC) techniques. They found that the results from the MC-IC measurements were about seven times higher than the LIF measurements. Nevertheless, the reported $\mathrm{NO}_{x}$ and HONO levels have a profound effect on the photochemistry of the polar boundary layer since both compounds are involved in the formation and destruction of $\mathrm{OH}$ and hydroperoxyl radicals $\left(\mathrm{HO}_{2}\right)$ and ozone [28,29], thus influencing the oxidation capacity of the boundary layer.

Although the strong impact of the $\mathrm{NO}_{3}^{-}$photolysis is evident, a full mechanistic understanding of the transformation of nitrogen-containing compounds in the snow is still not available. Previous laboratory studies have focused on different aspects, like the photolytic decomposition of $\mathrm{NO}_{3}{ }^{-}$[24,27], the formation of products like $\mathrm{OH}[20,22]$ and nitrite $\left(\mathrm{NO}_{2}{ }^{-}\right)$[19,20,27] and the release of $\mathrm{NO}_{x}$ to the gas phase $[18,19,21,23,25,26]$.

Here, we present a series of laboratory experiments performed with artificial snow samples. Results of photolysis experiments with different initial concentrations of $\mathrm{NO}_{3}{ }^{-}$and $\mathrm{NO}_{2}{ }^{-}$ are used to develop a reaction mechanism for the photochemical transformation of $\mathrm{NO}_{3}{ }^{-}$and $\mathrm{NO}_{2}{ }^{-}$. The mechanism is further adapted to conditions during previous field experiments performed at Summit, Greenland. The modeled results regarding the emissions of $\mathrm{NO}_{x}$ and $\mathrm{HONO}$ are compared to the field measurements, indicating that the main photochemical processes occurring in the natural snow-cover can successfully be reproduced using the proposed mechanism.

\section{Experimental methods}

Details of the preparation of artificial snow samples have been described previously [27,39]. In short, liquid solutions were prepared from Milli-Q water (resistance larger than $18 \mathrm{M} \Omega$ ) by adding sodium nitrate or sodium nitrite (both Merck, Darmstadt, Germany) and transferred into a stainless steel tank. From the pressurized tank the solution was sprayed into liquid nitrogen. In a cold room below $-25^{\circ} \mathrm{C}$, the resulting ice was ground with an electric mill, passed through a test sieve with a mesh size of $0.5 \mathrm{~mm}$, and stored at least overnight in $1 \mathrm{~L}$ glass bottles covered with aluminum foil.

The experimental set-up was similar to previously performed photolysis experiments [27,39]. A mercury-arc lamp (Oriel Instrument, Stratford, CT) with a maximum power input of about $1000 \mathrm{~W}$ was used as the light source. For the experiments the power input was reduced to $500 \mathrm{~W}$. A $10 \mathrm{~cm}$ long liquid-filter filled with Milli-Q water was directly coupled to the output of the lamp housing condenser to absorb the infrared radiation. The transmittance of the water filter was about $80 \%$ between the wavelengths of 250 and $700 \mathrm{~nm}$ [27]. An additional $10 \mathrm{~cm}$ long cylindrical extension made of white synthetic material was fixed to the end of the liquid-filter. The snow samples were filled into cylindrical $1 \mathrm{~cm}$ long Teflon cells, equipped with quartz windows. The reaction cells were easily attached to the end of the extension, which was equipped with a flange with an inner-diameter equal to the outer-diameter of the cells. The snow sample was completely illuminated by the light beam since the liquid-filter, the cylindrical extension, and the reaction cells had the same inner-diameter of $4.6 \mathrm{~cm}$ (Fig. 1).

The experiment was installed inside an opening of a freezer so that two-thirds of the extension and the entire reaction cell were located inside the freezer, which was regulated to a temperature of -31 to $-30^{\circ} \mathrm{C}$. Before each experiment, the filled cell was stored several hours in the freezer to assure that the temperature of the snow was in equilibrium with the freezer's temperature. To start and end the single experiments, the cell was either placed inside or removed from the flange of the extension reaching through a second, normally closed opening of the freezer.

The $\mathrm{NO}_{3}{ }^{-}$and $\mathrm{NO}_{2}{ }^{-}$concentrations in the snow were determined before and after each experiment. When filling the cell for a new experiment, a sample of the same batch of snow was kept in an airtight bottle. After the experiment, the snow was

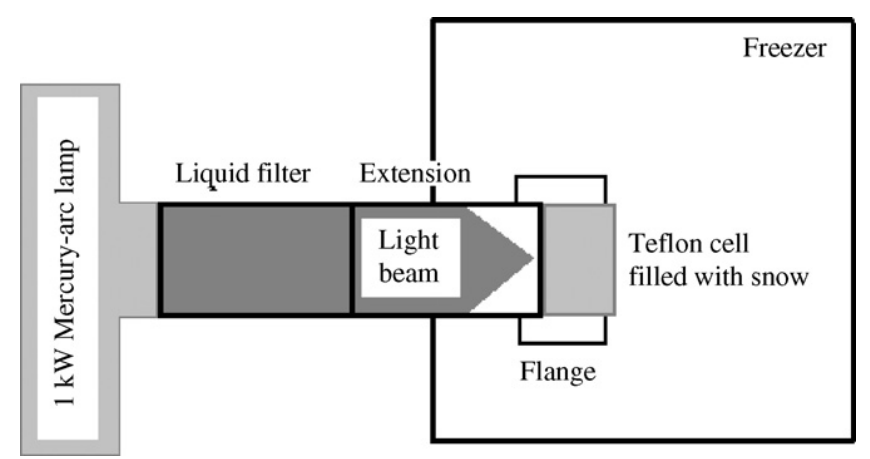

Fig. 1. Experimental system of the photolysis experiments. 
Table 1

Measured initial concentrations of $\mathrm{NO}_{3}{ }^{-}$and $\mathrm{NO}_{2}{ }^{-}$in the snow samples, calculated liquid QLL fraction, and corresponding calculated initial concentrations in the QLL

\begin{tabular}{|c|c|c|c|c|c|c|}
\hline \multirow[t]{2}{*}{ Batch } & \multirow[t]{2}{*}{ Temperature $\left({ }^{\circ} \mathrm{C}\right)$} & \multicolumn{2}{|c|}{$C_{\text {bulk }}{ }^{\mathrm{a}}(\mu \mathrm{M})$} & \multirow[t]{2}{*}{$\varphi_{\mathrm{H}_{2} \mathrm{O}}^{\mathrm{b}}\left(\times 10^{-5}\right)$} & \multicolumn{2}{|l|}{$C_{\mathrm{T}}^{0 \mathrm{c}}(\mathrm{mM})$} \\
\hline & & {$\left[\mathrm{NO}_{3}{ }^{-}\right]_{0}$} & {$\left[\mathrm{NO}_{2}{ }^{-}\right]_{0}$} & & {$\left[\mathrm{NO}_{3}{ }^{-}\right]_{0}$} & {$\left[\mathrm{NO}_{2}{ }^{-}\right]_{0}$} \\
\hline 1 & -31 & 10.84 & 0.161 & 3.42 & 317 & 4.71 \\
\hline 2 & -31 & 9.97 & 0.185 & 3.29 & 303 & 5.62 \\
\hline 3 & -30 & 1.66 & 3.28 & 2.33 & 71.2 & 141 \\
\hline 4 & -31 & 0.757 & 11.72 & 3.64 & 20.8 & 322 \\
\hline d & -20 & 12.55 & 0.084 & 4.65 & 270 & 1.80 \\
\hline e & -20 & 4.4 & 0 & 1.94 & 230 & 0 \\
\hline
\end{tabular}

${ }^{a}$ Concentrations measured in the melted snow samples.

b Liquid fraction calculated using Eq. (4).

c QLL concentrations calculated using Eq. (3).

d Concentrations and QLL fraction calculated for the experiments presented by Jacobi et al. [27].

e Concentrations and QLL fraction calculated for average $\mathrm{NO}_{3}{ }^{-}$concentration measured in surface snow during the summer of 2000 at Summit [11].

completely removed from the cell and filled into a second airtight bottle. The bottles were stored in the dark at $-20^{\circ} \mathrm{C}$ and the melted samples were analyzed using an ion chromatography system [27]. The system was always calibrated with a range of standard solutions and Milli-Q water before and after the analysis of the samples. The analytical error was $\pm 3 \times 10^{-8} \mathrm{M}$

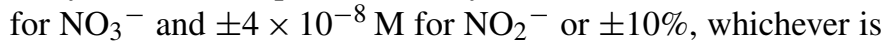
larger.

\section{Results}

Photolysis experiments with four different batches of artificial snow were performed with varying initial concentrations of $\mathrm{NO}_{3}{ }^{-}$and $\mathrm{NO}_{2}{ }^{-}$(Table 1). Batches 1 and 2 contained the highest initial $\mathrm{NO}_{3}{ }^{-}$concentrations $\left(\sim 10^{-5} \mathrm{M}\right)$ in the presence of almost negligible $\mathrm{NO}_{2}{ }^{-}$amounts. Irradiation caused a logarithmic decomposition of $\mathrm{NO}_{3}{ }^{-}$during the experiments (Fig. 2a). In the same experiments $\mathrm{NO}_{2}{ }^{-}$was first produced reaching a concentration maximum in the experiments lasting around $30 \mathrm{~min}$. Thereafter, $\mathrm{NO}_{2}{ }^{-}$decreased after longer irradiation periods. However, the behavior of both compounds changed with elevated initial $\mathrm{NO}_{2}{ }^{-}$concentrations. The results of the batches 3 and 4 demonstrate that with higher initial $\mathrm{NO}_{2}{ }^{-}$concentrations the drop in the $\mathrm{NO}_{3}{ }^{-}$concentrations was delayed or even absent (Fig. 2b and c). Increasing the $\mathrm{NO}_{2}{ }^{-}$concentration to $1.2 \times 10^{-5} \mathrm{M}$ even caused a significant production of $\mathrm{NO}_{3}{ }^{-}$ (Fig. 2c). On the other hand, the $\mathrm{NO}_{2}{ }^{-}$concentrations showed a steady decrease in the batches 3 and 4 with increasing irradiation times.

\section{Discussion}

\subsection{Development of a reaction mechanism for the transformation of $\mathrm{NO}_{3}{ }^{-}$and $\mathrm{NO}_{2}{ }^{-}$in snow}

The experimental results cannot be reconciled with the following previously proposed reaction sequence [27]:

$\mathrm{NO}_{3} \stackrel{-h v}{\longrightarrow} \mathrm{NO}_{2}-\stackrel{h v}{\longrightarrow} \mathrm{NO}_{x}$
Such a reaction sequence is in conflict with the observation of the formation of $\mathrm{NO}_{3}{ }^{-}$in the experiments with significant initial $\mathrm{NO}_{2}-$ concentrations. Additional reactions are needed to describe the experimental data. According to the known reaction

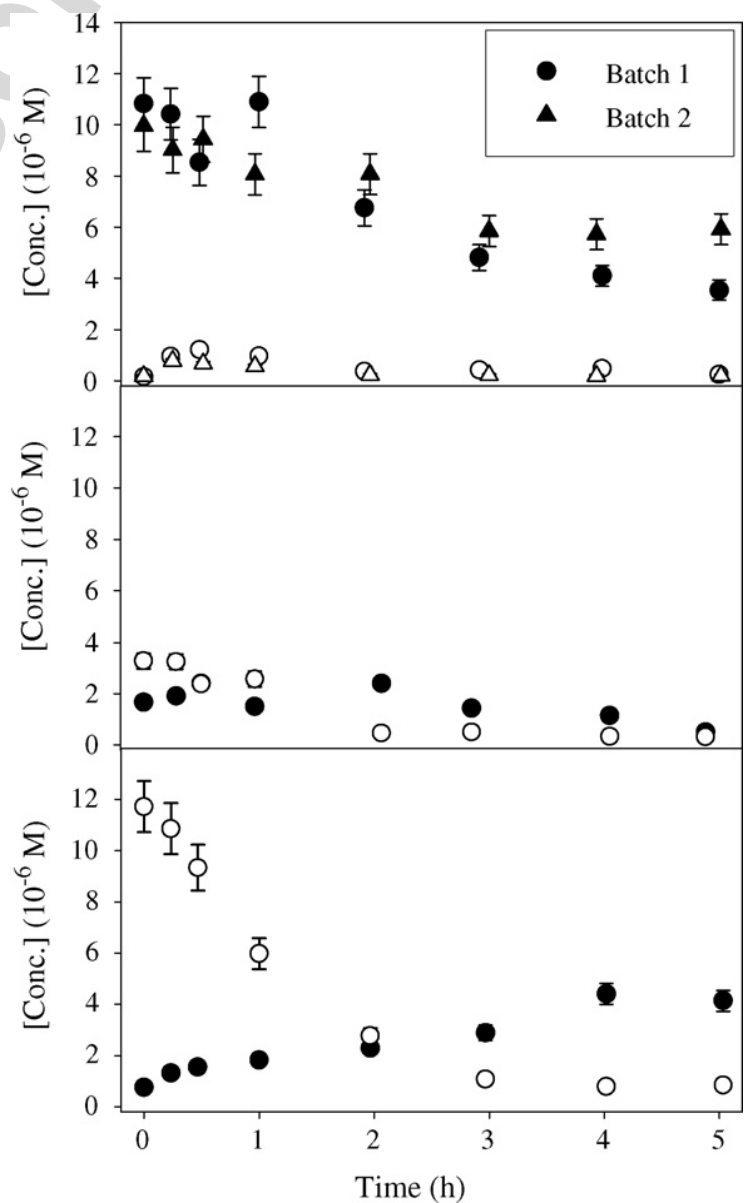

Fig. 2. Plots of the $\mathrm{NO}_{3}{ }^{-}$(filled symbols) and $\mathrm{NO}_{2}{ }^{-}$concentrations (open symbols) measured in the melted snow after each photolysis experiment vs. the duration of the experiments: (a) batches 1 and 2, (b) batch 3, and (c) batch 4 (initial concentrations see Table 1). Error bars represent analytical errors. If no error bar is visible, the errors are smaller than the size of the symbols. 
mechanism in the aqueous phase [33] $\mathrm{NO}_{2}{ }^{-}$can be oxidized to $\mathrm{NO}_{3}{ }^{-}$via the formation of nitrogen dioxide $\left(\mathrm{NO}_{2}\right)$. Using $\mathrm{NO}_{2}{ }^{-}$ as a precursor, $\mathrm{NO}_{2}$ formation can occur through two different pathways: attack by $\mathrm{OH}(\mathrm{R} 1)$ and photolysis of $\mathrm{NO}_{2}^{-}$(R2) with the subsequent oxidation of NO by dissolved oxygen (R3):

$\mathrm{NO}_{2}{ }^{-}+\mathrm{OH} \rightarrow \mathrm{NO}_{2}+\mathrm{OH}^{-}$

$\mathrm{NO}_{2}{ }^{-}\left(+\mathrm{H}^{+}\right) \stackrel{h v}{\longrightarrow} \mathrm{NO}+\mathrm{OH}$

$2 \mathrm{NO}+\mathrm{O}_{2} \rightarrow 2 \mathrm{NO}_{2}$

In the reaction (R2) an oxide radical ion $\left(\mathrm{O}^{-}\right)$is first generated, which immediately adds a proton to yield $\mathrm{OH}$ radicals [40]. $\mathrm{NO}_{2}$ can subsequently be oxidized to $\mathrm{NO}_{3}{ }^{-}$either by the formation of the dimer $\mathrm{N}_{2} \mathrm{O}_{4}$ followed by hydrolysis (R4) [25] or by the attack of an $\mathrm{OH}$ radical (R5):

$$
\begin{aligned}
& 2 \mathrm{NO}_{2}+\mathrm{H}_{2} \mathrm{O} \rightarrow \mathrm{NO}_{3}{ }^{-}+\mathrm{NO}_{2}{ }^{-}+2 \mathrm{H}^{+} \\
& \mathrm{NO}_{2}+\mathrm{OH} \rightarrow \mathrm{NO}_{3}{ }^{-}+\mathrm{H}^{+}
\end{aligned}
$$

Two reaction channels are possible during the photolysis of $\mathrm{NO}_{3}{ }^{-}$: either the formation of $\mathrm{NO}_{2}(\mathrm{R} 6)$ or $\mathrm{NO}_{2}{ }^{-}$(R7):

$\mathrm{NO}_{3}{ }^{-}\left(+\mathrm{H}^{+}\right) \stackrel{h v}{\longrightarrow} \mathrm{NO}_{2}+\mathrm{OH}$

$\mathrm{NO}_{3} \stackrel{-h v}{\longrightarrow} \mathrm{NO}_{2}^{-}+\mathrm{O}$

An additional product of reaction $(\mathrm{R} 7)$ is the oxygen atom $(\mathrm{O})$. It can react with dissolved oxygen to produce ozone (R8) and with $\mathrm{NO}_{3}{ }^{-}$producing additional $\mathrm{NO}_{2}{ }^{-}(\mathrm{R} 9)$ :

$\mathrm{O}+\mathrm{O}_{2} \rightarrow \mathrm{O}_{3}$
$\mathrm{NO}_{3}{ }^{-}+\mathrm{O} \rightarrow \mathrm{NO}_{2}{ }^{-}+\mathrm{O}_{2}$
Additional reactions leading to the formation of $\mathrm{NO}_{2}{ }^{-}$is the reaction of $\mathrm{OH}$ with $\mathrm{NO}$ (R10) and the reaction of NO with $\mathrm{NO}_{2}$ with the subsequent hydrolysis of $\mathrm{N}_{2} \mathrm{O}_{3}$ (R11):

$$
\begin{aligned}
& \mathrm{NO}+\mathrm{OH} \rightarrow \mathrm{NO}_{2}{ }^{-}+\mathrm{H}^{+} \\
& \mathrm{NO}+\mathrm{NO}_{2}+\mathrm{H}_{2} \mathrm{O} \rightarrow 2 \mathrm{NO}_{2}{ }^{-}+2 \mathrm{H}^{+}
\end{aligned}
$$

Due to the experimental conditions, we also need to take into account the photolysis of $\mathrm{NO}_{2}$ to $\mathrm{NO}$ in the snow (R12):

$\mathrm{NO}_{2} \stackrel{h v}{\longrightarrow} \mathrm{NO}+\mathrm{O}$

Finally, due to the low solubility the nitrogen oxides are transferred to the gas phase (R13) and (R14):

$\mathrm{NO} \rightarrow \mathrm{NO}_{\text {gas }}$
$\mathrm{NO}_{2} \rightarrow \mathrm{NO}_{2}$ gas

The full reaction mechanism used for the analysis of the experimental data is shown in Table 2. We used aqueous phase kinetic data for the rate constants of the bimolecular reactions. If temperature-dependent rate constants were available, they were extrapolated to sub-freezing temperatures (Table 2).

The rate constants of the $\mathrm{NO}_{2}{ }^{-}$and $\mathrm{NO}_{3}{ }^{-}$photolysis reactions (R2), (R6), and (R7) and the rates for the phase transfer reactions of $\mathrm{NO}$ and $\mathrm{NO}_{2}((\mathrm{R} 13)$ and (R14)), were derived by fitting the experimental and calculated concentration-time curves using the commercial FACSIMILE software. For the fitting procedure we used the measured $\mathrm{NO}_{3}{ }^{-}$and $\mathrm{NO}_{2}{ }^{-}$concentrations and gas phase $\mathrm{NO}_{x \text { gas }}$ concentrations. Since $\mathrm{NO}_{x \text { gas }}$ was not directly measured, we calculated the gas phase concentration as the difference from the measured $\left(\left[\mathrm{NO}_{3}{ }^{-}\right],\left[\mathrm{NO}_{2}{ }^{-}\right]\right)$to the

\begin{tabular}{|c|c|c|c|c|c|}
\hline \multirow[t]{2}{*}{ Reaction no. } & & \multicolumn{3}{|l|}{ Reaction rates ${ }^{\mathrm{a}}$} & \multirow[t]{2}{*}{ Reference } \\
\hline & & $T=-31^{\circ} \mathrm{C}$ & $T=-20^{\circ} \mathrm{C}$ & Summit $^{b}$ & \\
\hline $\mathrm{OH}+\mathrm{NO}_{2}^{-} \rightarrow \mathrm{NO}_{2}+\mathrm{OH}^{-}$ & (R1) & $1 \times 10^{10} \mathrm{M}^{-1} \mathrm{~s}^{-1}$ & $1 \times 10^{10} \mathrm{M}^{-1} \mathrm{~s}^{-1}$ & $1 \times 10^{10} \mathrm{M}^{-1} \mathrm{~s}^{-1}$ & [41] \\
\hline$(\mathrm{R} 2) \mathrm{NO}_{2}{ }^{-}\left(+\mathrm{H}^{+}\right) \stackrel{h v}{\longrightarrow} \mathrm{NO}+\mathrm{OH}$ & & $3 \times 10^{-3} \mathrm{~s}^{-1 \mathrm{c}}$ & $8.4 \times 10^{-3} \mathrm{~s}^{-1 \mathrm{~d}}$ & $2.5 \times 10^{-5} \mathrm{~s}^{-1}$ & This work \\
\hline $2 \mathrm{NO}+\mathrm{O}_{2} \rightarrow 2 \mathrm{NO}_{2}$ & (R3) & $360 \mathrm{M}^{-1} \mathrm{~s}^{-1 \mathrm{e}}$ & $420 \mathrm{M}^{-1} \mathrm{~s}^{-1 \mathrm{e}}$ & $420 \mathrm{M}^{-1} \mathrm{~s}^{-1 \mathrm{e}}$ & [42] \\
\hline $2 \mathrm{NO}_{2}+\mathrm{H}_{2} \mathrm{O} \rightarrow \mathrm{NO}_{3}^{-}+\mathrm{NO}_{2}{ }^{-}+2 \mathrm{H}^{+}$ & (R4) & $1 \times 10^{7} \mathrm{M}^{-1} \mathrm{~s}^{-1}$ & $1.4 \times 10^{7} \mathrm{M}^{-1} \mathrm{~s}^{-1}$ & $1.4 \times 10^{7} \mathrm{M}^{-1} \mathrm{~s}^{-1}$ & [43] \\
\hline $\mathrm{NO}_{2}+\mathrm{OH} \rightarrow \mathrm{H}^{+}+\mathrm{NO}_{3}^{-}$ & (R5) & $5 \times 10^{9} \mathrm{M}^{-1} \mathrm{~s}^{-1}$ & $5 \times 10^{9} \mathrm{M}^{-1} \mathrm{~s}^{-1}$ & $5 \times 10^{9} \mathrm{M}^{-1} \mathrm{~s}^{-1}$ & [44] \\
\hline$\left(\mathrm{R}^{2}\right) \mathrm{NO}_{3}{ }^{-}\left(+\mathrm{H}^{+}\right) \stackrel{h v}{\longrightarrow} \mathrm{NO}_{2}+\mathrm{OH}$ & & $1 \times 10^{-4} \mathrm{~s}^{-1 \mathrm{c}}$ & $2.8 \times 10^{-4} \mathrm{~s}^{-1 \mathrm{~d}}$ & $8.3 \times 10^{-7} \mathrm{~s}^{-1}$ & This work \\
\hline$(\mathrm{R} 7) \mathrm{NO}_{3}{ }^{-} \stackrel{h v}{\longrightarrow} \mathrm{NO}_{2}^{-}+\mathrm{O}$ & & $2 \times 10^{-5} \mathrm{~s}^{-1 \mathrm{c}}$ & $5.6 \times 10^{-5} \mathrm{~s}^{-1 \mathrm{~d}}$ & $1.7 \times 10^{-7} \mathrm{~s}^{-1}$ & This work \\
\hline $\mathrm{O}+\mathrm{O}_{2} \rightarrow \mathrm{O}_{3}$ & (R8) & $1.2 \times 10^{6} \mathrm{~s}^{-1 \mathrm{e}}$ & $1.2 \times 10^{6} \mathrm{~s}^{-1 \mathrm{e}}$ & $1.2 \times 10^{6} \mathrm{~s}^{-1 \mathrm{e}}$ & [45] \\
\hline $\mathrm{NO}_{3}^{-}+\mathrm{O} \rightarrow \mathrm{NO}_{2}^{-}+\mathrm{O}_{2}$ & (R9) & $2 \times 10^{8} \mathrm{M}^{-1} \mathrm{~s}^{-1}$ & $2 \times 10^{8} \mathrm{M}^{-1} \mathrm{~s}^{-1}$ & $2 \times 10^{8} \mathrm{M}^{-1} \mathrm{~s}^{-1}$ & [19] \\
\hline $\mathrm{NO}+\mathrm{OH} \rightarrow \mathrm{H}^{+}+\mathrm{NO}_{2}^{-}$ & (R10) & $2 \times 10^{10} \mathrm{M}^{-1} \mathrm{~s}^{-1}$ & $2 \times 10^{10} \mathrm{M}^{-1} \mathrm{~s}^{-1}$ & $2 \times 10^{10} \mathrm{M}^{-1} \mathrm{~s}^{-1}$ & [46] \\
\hline $\mathrm{NO}+\mathrm{NO}_{2}+\mathrm{H}_{2} \mathrm{O} \rightarrow 2 \mathrm{NO}_{2}^{-}+2 \mathrm{H}^{+}$ & (R11) & $3 \times 10^{8} \mathrm{M}^{-1} \mathrm{~s}^{-1}$ & $3 \times 10^{8} \mathrm{M}^{-1} \mathrm{~s}^{-1}$ & $3 \times 10^{8} \mathrm{M}^{-1} \mathrm{~s}^{-1}$ & {$[47]$} \\
\hline$(\mathrm{R} 12) \mathrm{NO}_{2} \stackrel{h v}{\longrightarrow} \mathrm{NO}+\mathrm{O}$ & & $1 \mathrm{~s}^{-1}$ & $2.8 \mathrm{~s}^{-1}$ & $8.3 \times 10^{-3} \mathrm{~s}^{-1}$ & Estimated \\
\hline $\mathrm{NO} \rightarrow \mathrm{NO}_{\mathrm{gas}}$ & (R13) & $45 s^{-1 c}$ & $57 s^{-1 d}$ & $57 s^{-1}$ & This work \\
\hline $\mathrm{NO}_{2} \rightarrow \mathrm{NO}_{2}$ gas & (R14) & $3 \mathrm{~s}^{-1 \mathrm{c}}$ & $9.7 \mathrm{~s}^{-1 \mathrm{~d}}$ & $9.7 \mathrm{~s}^{-1}$ & This work \\
\hline
\end{tabular}
initial $\mathrm{NO}_{3}{ }^{-}$and $\mathrm{NO}_{2}{ }^{-}$concentrations $\left(\left[\mathrm{NO}_{3}{ }^{-}\right]_{0},\left[\mathrm{NO}_{2}{ }^{-}\right]_{0}\right)$ in

Table 2

Reactions included in the mechanism for the photochemical transformation of $\mathrm{NO}_{3}{ }^{-}$and $\mathrm{NO}_{2}{ }^{-}$in snow

${ }^{a}$ Reaction rates were taken from kinetic data determined in the aqueous liquid phase. If temperature-dependent rate constants were available, reaction rates were extrapolated to sub-freezing temperatures.

b Reaction rates estimated for conditions at GEO Summit in summer 2000.

c Reaction rates determined for experiments here, performed at $-31^{\circ} \mathrm{C}$.

${ }^{\mathrm{d}}$ Reaction rates determined for previously published experiments [27], performed at $-20^{\circ} \mathrm{C}$.

e First- and second-order rate constants calculated with $\left[\mathrm{O}_{2}\right]=0.3 \mu \mathrm{M}[19]$. 
the snow:

$$
\left[\mathrm{NO}_{x \text { gas }}\right]=\left[\mathrm{NO}_{3}{ }^{-}\right]_{0}+\left[\mathrm{NO}_{2}^{-}\right]_{0}-\left(\left[\mathrm{NO}_{3}{ }^{-}\right]+\left[\mathrm{NO}_{2}{ }^{-}\right]\right)
$$

Although the $\mathrm{NO}_{x}$ transfer rates $k_{\mathrm{R} 13}$ and $k_{\mathrm{R} 14}$ varied, we always used a fixed ratio of $k_{\mathrm{R} 13} / k_{\mathrm{R} 14}=15$ since the extrapolated Henry's law constants of both compounds at $T=31{ }^{\circ} \mathrm{C}$ differ by a factor of 15 [48]. This assumption is in agreement with previous laboratory experiments suggesting that $\mathrm{NO}_{2}$ is more strongly bound than NO to the ice [26].

Several laboratory studies have provided evidence that the photolysis of nitrate and the subsequent reactions in ice and snow take place in a so-called quasi-liquid layer (QLL) on the surface of ice crystals $[19,20,22,23]$. Although the properties of the QLL are not well established, it is now well known that at temperatures close to the melting point and/or in the presence of impurities, the QLL shows a strongly enhanced disorder compared to the highly ordered interior of the ice crystal (e.g. [49-53]). Nevertheless, the QLL is always restricted to a limited number of layers of water molecules. If all reactions in the condensed phase take place in this much smaller volume, the calculations must be performed using significantly higher concentrations. Cho et al. [51] performed NMR spectroscopy to determine the fraction of water in the QLL $\varphi_{\mathrm{H}_{2} \mathrm{O}}$ as a function of temperature $T$ and the total solute concentration in the QLL $C_{\mathrm{T}}^{0}$. They obtained the following equation (2):

$\varphi_{\mathrm{H}_{2} \mathrm{O}}(T)=\frac{m_{\mathrm{H}_{2} \mathrm{O}} R T_{\mathrm{f}}}{1000 H_{\mathrm{f}}^{0}} \frac{T}{T-T_{\mathrm{f}}} C_{\mathrm{T}}^{0}$
Here, $m_{\mathrm{H}_{2} \mathrm{O}}$ is the molecular weight of water, $R$ the gas constant, $H_{\mathrm{f}}^{0}$ the melting enthalpy of water, and $T_{\mathrm{f}}$ is the freezing temperature of water.

The concentration in the QLL is not directly available for our experiments since the analysis of the melted snow samples yields only the bulk snow concentrations. Nevertheless, these can be translated into the QLL concentrations if we assume that all impurities are located in the QLL. In that case, we can relate the bulk concentration $C_{\text {bulk }}$ to the QLL concentrations $C_{\mathrm{T}}^{0}$ by the following Eq. (3):

$C_{\text {bulk }}=\varphi_{\mathrm{H}_{2} \mathrm{O}}(T) C_{\mathrm{T}}^{0}$

Substituting this expression into Eq. (2), we find

$\varphi_{\mathrm{H}_{2} \mathrm{O}}(T)=\sqrt{\frac{m_{\mathrm{H}_{2} \mathrm{O}} R T_{\mathrm{f}}}{1000 H_{\mathrm{f}}^{0}} \frac{T}{T-T_{\mathrm{f}}} C_{\text {bulk }}}$

The QLL fractions $\left(\varphi_{\mathrm{H}_{2} \mathrm{O}}\right.$ listed in Table 1 were obtained with Eq. (4) for the initial conditions of the four different snow batches. Applying Eq. (3), $\varphi_{\mathrm{H}_{2} \mathrm{O}}$ was subsequently used to calculate QLL concentrations of $\mathrm{NO}_{3}{ }^{-}$and $\mathrm{NO}_{2}{ }^{-}$for the experiments performed with the four snow batches as shown in Table 1 for the initial concentrations. Fig. 3 shows the results of all four batches transformed into QLL concentration and also the gas phase $\mathrm{NO}_{x}$ concentrations as calculated from the differences between actual and initial $\mathrm{NO}_{3}{ }^{-}$and $\mathrm{NO}_{2}{ }^{-}$concentrations in the snow according to Eq. (1). For an easier comparison the $\mathrm{NO}_{x \text { gas }}$ concentrations are also plotted in $\mathrm{M}$ units like the QLL concentrations.

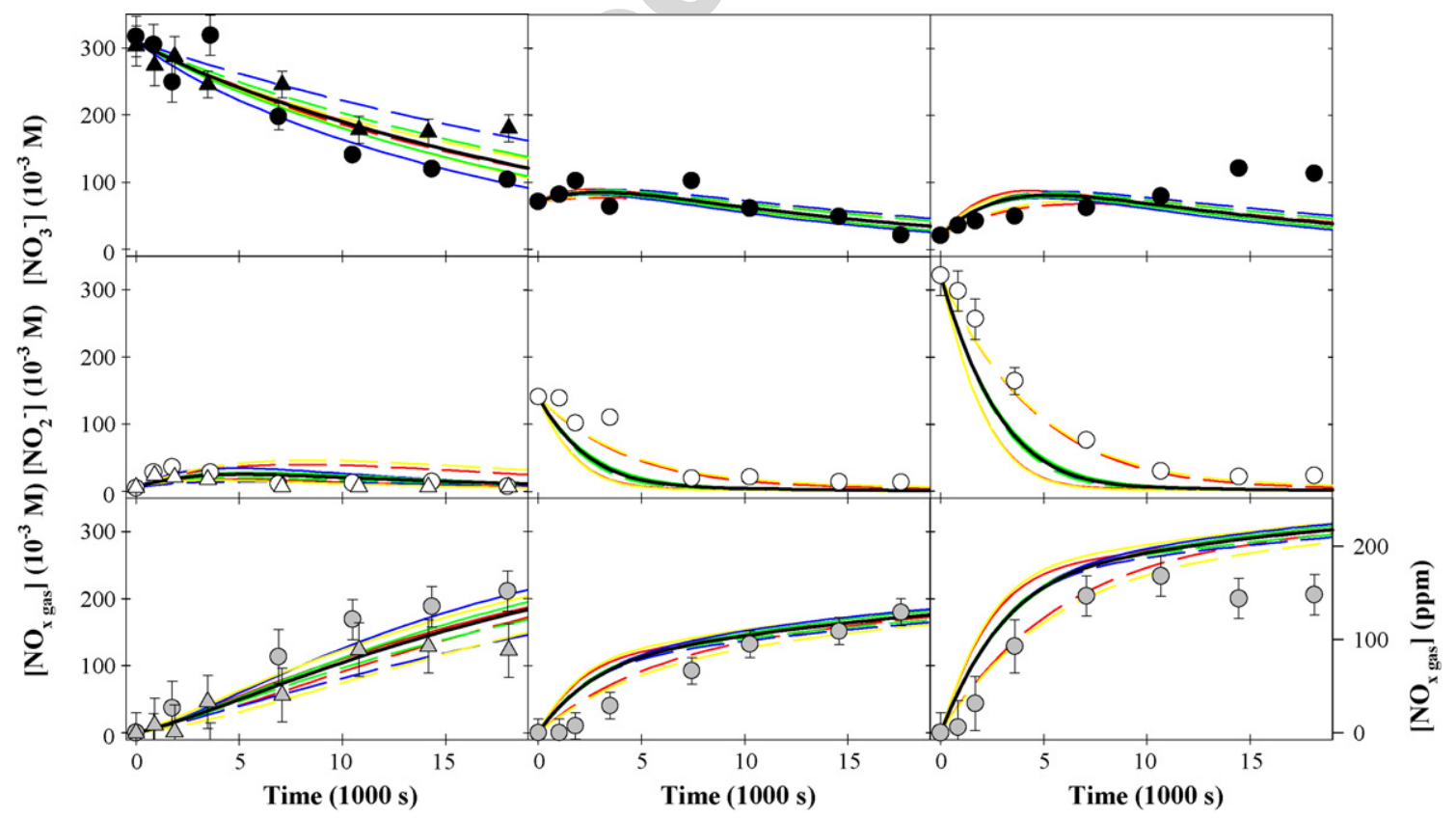

Fig. 3. Comparison of experimental and calculated concentration-time-profiles for $\mathrm{NO}_{3}{ }^{-}$(top) and $\mathrm{NO}_{2}{ }^{-}$concentrations (middle) in the $\mathrm{QLL}$ and $\mathrm{NO}_{x}$ gas in the gas phase (bottom) for the snow batches 1 and 2 (left), batch 3 (middle), and batch 4 (right). On the left axis the $\mathrm{NO}_{x}$ concentration is shown in $\mathrm{M}$ as calculated according to Eq. (1) as the deficit of $\mathrm{NO}_{3}{ }^{-}$and $\mathrm{NO}_{2}{ }^{-}$in the snow samples. On the right axis the $\mathrm{NO}_{x}$ concentrations are transformed into gas phase mixing ratios taking into account the mass of the snow and the gas phase volume in the cell. The black line represents calculated profiles using the optimum rate constants (see text). Colored lines represent calculated profiles with single rate constants varying by $+50 \%$ (full lines) and $-50 \%$ (dashed lines) with variation of $k_{\mathrm{R} 2}$ : red, $k_{\mathrm{R} 7}$ : blue, $k_{\mathrm{R} 6}$ : green, and $k_{\mathrm{R} 13}$ and $k_{\mathrm{R} 14}$ : yellow. Error bars for $\mathrm{NO}_{3}{ }^{-}$and $\mathrm{NO}_{2}{ }^{-}$represent analytical errors. The error of the gas phase $\mathrm{NO}_{x}$ is calculated from the analytical errors of $\mathrm{NO}_{3}{ }^{-}$and $\mathrm{NO}_{2}{ }^{-}$using error propagation. If no error bar is visible, the errors are smaller than the size of the symbols. 
A common best-fit was determined using the QLL concentrations of all four batches of snow shown in Fig. 3. Best agreement between the experiments and the calculated concentration-timeprofiles were found with the following rate constants for the photolytic reactions of $\mathrm{NO}_{2}^{-}$and $\mathrm{NO}_{3}^{-}: k_{\mathrm{R} 2}=3 \times 10^{-3} \mathrm{~s}^{-1}$ $k_{\mathrm{R} 6}=1 \times 10^{-4} \mathrm{~s}^{-1}$, and $k_{\mathrm{R} 7}=2 \times 10^{-5} \mathrm{~s}^{-1}$. Thus, in our experiments the photolysis of $\mathrm{NO}_{2}{ }^{-}$occurred a factor of $\sim 25$ faster than the overall photolysis of $\mathrm{NO}_{3}{ }^{-}$. The two different reaction channels for the $\mathrm{NO}_{3}{ }^{-}$photolysis, generating $\mathrm{NO}_{2}$ (R6) and $\mathrm{NO}_{2}{ }^{-}$(R7), contributed $83 \%$ and $17 \%$, respectively, which is in reasonable agreement with previous studies in fluid and frozen media [19,21,22,33].

In addition, the optimum transfer rates for $\mathrm{NO}$ and $\mathrm{NO}_{2}$ were determined to be on the order of $k_{\mathrm{R} 13}=45 \mathrm{~s}^{-1}$ and $k_{\mathrm{R} 14}=3 \mathrm{~s}^{-1}$, respectively. Fig. 3 shows a comparison of the time series of experimental and modeled QLL concentrations obtained with the optimum rate constants. The sensitivities of the calculated concentrations to changes in the rate constants were tested. The reaction rate constants $k_{\mathrm{R} 2}, k_{\mathrm{R} 6}$, and $k_{\mathrm{R} 7}$ and the transfer constants $k_{\mathrm{R} 13}$ and $k_{\mathrm{R} 14}$ were separately changed by a factor of 2 (the ratio of $k_{\mathrm{R} 13}$ to $k_{\mathrm{R} 14}$ remained constant). The results of these sensitivity studies are also shown in Fig. 3.

In general, the calculated concentrations are in good agreement with the experimental data. The deviations between modeled and experimental data are in the same range as the variability of the results for the two different snow batches 1 and 2 with comparable initial concentrations. Applying the mechanism, we are able to reproduce the reduction in $\mathrm{NO}_{3}{ }^{-}$and $\mathrm{NO}_{2}{ }^{-}$if high initial concentrations of either compound were present in the snow. The mechanism also captures the transformation of $\mathrm{NO}_{2}^{-}$ to $\mathrm{NO}_{3}{ }^{-}$observed in the batches 3 and 4 (Fig. 3). The quick release of nitrogen oxides to the gas phase is also well reproduced by the model. However, the $\mathrm{NO}_{2}{ }^{-}$drop occurs somewhat faster in the model compared to the experiments performed with the batches 2 and 3. Better agreement is obtained if either the rate constant $k_{\mathrm{R} 2}$ for the photolysis of $\mathrm{NO}_{2}{ }^{-}$(dashed red line) or the transfer rates $k_{\mathrm{R} 13}$ and $k_{\mathrm{R} 14}$ of $\mathrm{NO}$ and $\mathrm{NO}_{2}$ (dashed yellow line) were reduced by $50 \%$ (Fig. 3). However, these higher rates would lead to a much worse agreement with the results of the batches 1 and 2 with small initial $\mathrm{NO}_{2}^{-}$concentrations. Therefore, the proposed rate constants constitute a compromise for all four experiments. The gas phase $\mathrm{NO}_{x}$ concentrations are also sensitive to the rate constants $k_{\mathrm{R} 2}, k_{\mathrm{R} 13}$, and $k_{\mathrm{R} 14}$. Similar to $\mathrm{NO}_{2}{ }^{-}$, the agreement between modeled and measured $\mathrm{NO}_{x}$ becomes better with higher rate constants for the batches 3 and 4 and worse for the batches 1 and 2 . In contrast, the calculated $\mathrm{NO}_{3}{ }^{-}$concentrations are most sensitive to the photolysis rate constants $k_{\mathrm{R} 6}$ and $k_{\mathrm{R} 7}$ of $\mathrm{NO}_{3}{ }^{-}$.

\subsection{Comparison with previous laboratory data}

Jacobi et al. [27] previously presented results of similar experiments regarding the photolytic decomposition of nitrate in snow. Here, we apply the newly developed reaction mechanism to reproduce the experimental data. However, due to the different experimental conditions the rate constants need to be adjusted. First, the distance between the reaction cell and the lamp was

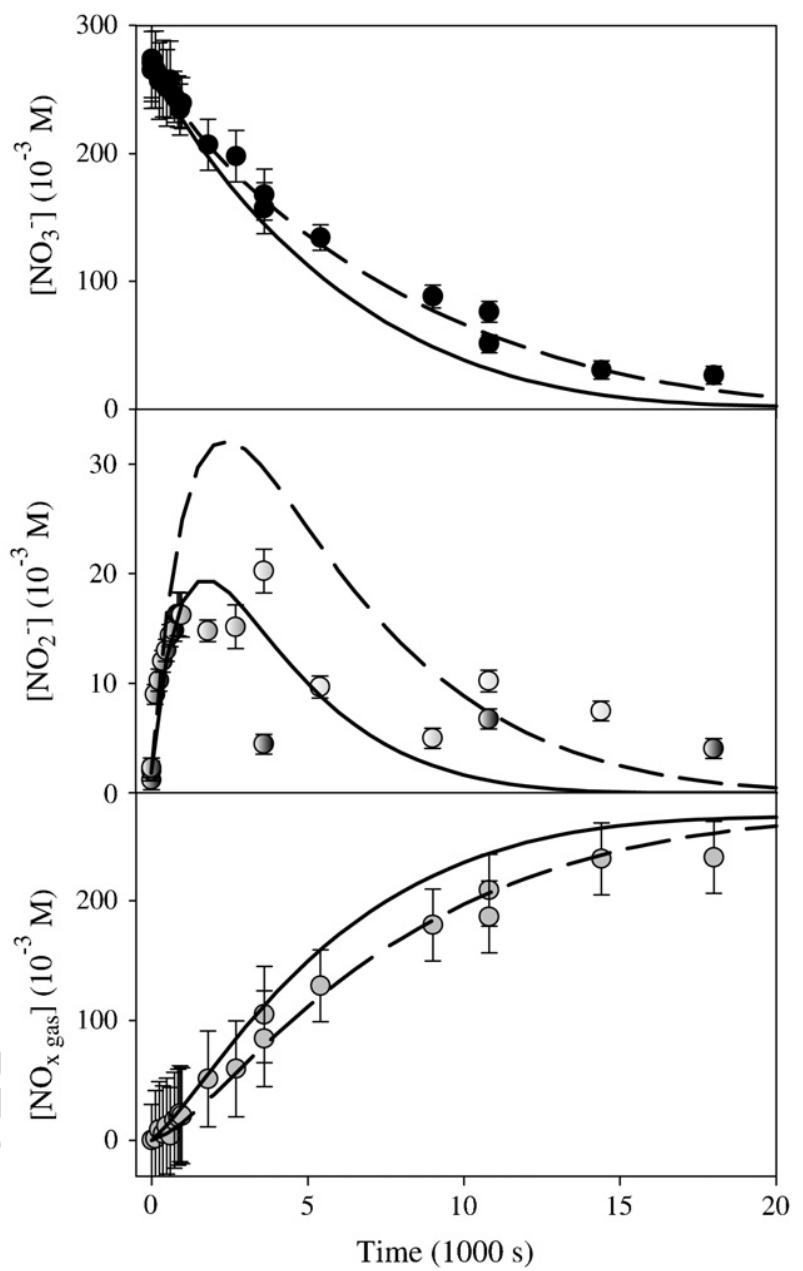

Fig. 4. Comparison of experimental and calculated concentration-time-profiles for $\mathrm{NO}_{3}{ }^{-}$(top) and $\mathrm{NO}_{2}{ }^{-}$concentrations (middle) in the QLL and $\mathrm{NO}_{x}$ in the gas phase (bottom) for previous experiments [27] performed at $-20{ }^{\circ} \mathrm{C}$. $\mathrm{The}^{\mathrm{N} \mathrm{N}_{x}}$ concentrations are calculated according to Eq. (1). The dashed line represents calculated profiles with all photolysis rates multiplied by 2.8 (see text). The full lines represent calculated profiles with increased photolysis rates and increased transfer rates for $\mathrm{NO}$ and $\mathrm{NO}_{2}$ as summarized in Table 2 (see text). Error bars for $\mathrm{NO}_{3}{ }^{-}$and $\mathrm{NO}_{2}{ }^{-}$represent analytical errors. The error of the gas phase $\mathrm{NO}_{x}$ is calculated from the analytical errors of $\mathrm{NO}_{3}{ }^{-}$and $\mathrm{NO}_{2}{ }^{-}$using error propagation.

smaller in the previous experimental set-up $(16 \mathrm{~cm})$, compared to the current set-up $(27 \mathrm{~cm})$. These different distances caused higher radiation intensities per area by a factor of 2.8 since the intensity decreases with the square of the distances from the light source. Therefore, we increased all photolysis rates $\left(k_{\mathrm{R} 2}\right.$, $k_{\mathrm{R} 6}, k_{\mathrm{R} 7}$, and $k_{\mathrm{R} 12}$ ) by a factor of 2.8 (Table 2 ). Second, the previous experiments were performed at a higher temperature of $-20^{\circ} \mathrm{C}$ [27]. We adjusted the rate constants $k_{\mathrm{R} 3}$ and $k_{\mathrm{R} 4}$ using the temperature dependencies of the rate constants reported in the literature $[42,43]$. However, the changes are smaller $(\leq 40 \%)$ than the assumed error of the fitted photolysis rate constants (Table 2). Fig. 4 shows calculated concentration-time-profiles with the increased photolysis and reaction rates. Moreover, the temperature also influences the phase transfer. Using, again, Henry's law constants as a reference, we find that the con- 
stant for NO decreases from $5.6 \times 10^{-3} \mathrm{M} \mathrm{atm}^{-1}$ at $-31^{\circ} \mathrm{C}$ to $4.4 \times 10^{-3} \mathrm{M} \mathrm{atm}^{-1}$ at $-20^{\circ} \mathrm{C}[48]$. The decrease is even more pronounced for $\mathrm{NO}_{2}$ from $8.4 \times 10^{-2} \mathrm{M}$ atm $^{-1}$ at $-31^{\circ} \mathrm{C}$ to $2.6 \times 10^{-2} \mathrm{M} \mathrm{atm}^{-1}$ at $-20^{\circ} \mathrm{C}$ [48]. Therefore, we enhanced the transfer constants similarly (Table 2), reducing the ratio of $k_{\mathrm{R} 13}$ to $k_{\mathrm{R} 14}$ from 15 at $-31^{\circ} \mathrm{C}$ to smaller than 6 at $-20^{\circ} \mathrm{C}$. Calculated concentration-time-profiles with the increased transfer rates are also shown in Fig. 4. The comparison with the experimental data shows that the agreement for $\mathrm{NO}_{2}{ }^{-}$is much improved with the higher transfer rates. With the lower transfer rates the maximum $\mathrm{NO}_{2}{ }^{-}$concentration is approximately $50 \%$ higher than the highest $\mathrm{NO}_{2}{ }^{-}$concentrations determined in any of the experiments. The higher transfer rates lead to maximum $\mathrm{NO}_{2}{ }^{-}$concentrations, which fall well in the range of the observed concentrations. On the other hand, the faster transfer leads to slightly overestimated values for the $\mathrm{NO}_{x}$ concentrations in the gas phase and slightly underestimated values for $\mathrm{NO}_{3}{ }^{-}$. The discrepancies become larger for experiments lasting longer than $5000 \mathrm{~s}(\approx 1.4 \mathrm{~h})$ and might be due to the equilibrium of $\mathrm{NO}$ and $\mathrm{NO}_{2}$ between the gas phase and the QLL. If the gas phase concentrations are sufficiently high a transfer back from the gas phase to the QLL becomes possible. This could explain the slightly lower gas phase and slightly higher $\mathrm{NO}_{3}{ }^{-}$concentrations observed in the experiments.

\subsection{Comparison with field data: $N O_{x}$ emissions}

Having established a mechanism for the photochemical transformation of nitrogen containing compounds in snow, we can apply this mechanism to previous field observations. The most comprehensive data set, which provides the needed input information, is currently available from measurements performed at the Greenland environmental observatory summit (GEO Summit) on top of the Greenland ice sheet $\left(72.6^{\circ} \mathrm{N}, 38.5^{\circ} \mathrm{W}, 3200 \mathrm{~m}\right.$ elevation) in the summer of the year 2000 . For example, nitrate photolysis rate coefficients were directly measured in the snow using chemical actinometry [10]. Average values for midday exposures were on the order of $10^{-6} \mathrm{~s}^{-1}$ at depths smaller than $5 \mathrm{~cm}$. Therefore, we decreased the rate coefficients $k_{\mathrm{R} 6}$ and $k_{\mathrm{R} 7}$ so that the sum of both photolysis rates gives a value of $10^{-6} \mathrm{~s}^{-1}$ (Table 2). Accordingly, we also reduced the photolysis rates $k_{\mathrm{R} 2}$ of $\mathrm{NO}_{2}{ }^{-}$and $k_{\mathrm{R} 12}$ of $\mathrm{NO}_{2}$ by the same factor, since this reaction will also be much slower under natural conditions. The reported snow temperatures for Summit varied between $-4{ }^{\circ} \mathrm{C}$ at the surface and $-21^{\circ} \mathrm{C}$ at a depth of $15 \mathrm{~cm}$ for the period of the photolysis rate measurements [10]. Although the experimental temperature of $-20^{\circ} \mathrm{C}$ is close to the lower limit of the temperature in the natural snow, we did not attempt to adjust the rate constants further. $\mathrm{NO}_{3}{ }^{-}$in surface-snow at Summit shows considerable short-term variability [54]. We used an average concentration of $3 \mu \mathrm{M}$ as reported by Dibb et al. [54] for the initial concentration in our calculations.

The rate constants and the initial calculated QLL concentration of $\mathrm{NO}_{3}{ }^{-}$are summarized in Tables 1 and 2. QLL concentrations and gas phase $\mathrm{NO}_{x}$ production rates simulated after reaction times of 2 and $4 \mathrm{~h}$ are shown in Table 3. Fig. 5 shows a concentration and flux diagram for conditions after reaction times of $2 \mathrm{~h}$. The diagram shows the conversion of the nitrogen compounds in the QLL and the transfer to the gas phase.

For the applied conditions the model predicts that the photochemical transformation of $\mathrm{NO}_{3}{ }^{-}$occurs very slowly. For example, after a reaction time of $4 \mathrm{~h}$ the $\mathrm{NO}_{3}{ }^{-}$concentrations are apparently reduced by less than $1 \%$ compared to the initial $\mathrm{NO}_{3}{ }^{-}$concentration, although the observed photolysis rate suggests that in such a period almost $1.4 \%$ of the initial $\mathrm{NO}_{3}{ }^{-}$would have been photolyzed. Obviously, the recycling of $\mathrm{NO}_{3}{ }^{-}$via the oxidation of $\mathrm{NO}_{2}$ contributes to the slower apparent $\mathrm{NO}_{3}{ }^{-}$ decrease. Fig. 5 shows that after a reaction time of $2 \mathrm{~h}$ the total sink strength of $\mathrm{NO}_{3}{ }^{-}$via the photolysis reactions (R6) and (R7) and the reaction with the $\mathrm{O}$ atom (R9) assumes a value of $2.7 \times 10^{-7} \mathrm{M} \mathrm{s}^{-1}$. However, the net destruction of $\mathrm{NO}_{3}{ }^{-}$is reduced by more than $40 \%$ due to the oxidation of $\mathrm{NO}_{2}$ to $\mathrm{NO}_{3}{ }^{-}$ mainly via the reaction with $\mathrm{OH}$ (R5).

$\mathrm{NO}_{2}{ }^{-}$concentrations in the QLL increase quickly and reach maximum values of $5.9 \times 10^{-9} \mathrm{M}$ after just several seconds before they decrease slowly. Translating the QLL concentrations into bulk snow concentrations using the QLL fraction (Table 2) leads to extremely small $\mathrm{NO}_{2}{ }^{-}$concentrations of less than $2 \times 10^{-13} \mathrm{M}$ in the snow. Such concentrations are far beyond the detection limit of currently used chemical snow analysis methods (e.g. [55-57]). Nevertheless, $\mathrm{NO}_{2}{ }^{-}$concentrations up to $1.8 \times 10^{-7} \mathrm{M}$ in arctic snow samples were reported at depths of $25 \mathrm{~cm}$, while the concentrations remained below $7 \times 10^{-8} \mathrm{M}$ at the surface [58]. A photochemical generation of such high $\mathrm{NO}_{2}{ }^{-}$concentrations is only possible with radiation intensities as high as in our laboratory experiments (Fig. 2). Since these intensities are orders of magnitudes higher than the intensity of the solar radiation at the Earth's surface [39], additional sources of $\mathrm{NO}_{2}{ }^{-}$must be invoked to explain the $\mathrm{NO}_{2}{ }^{-}$observations. Such sources could be the dry deposition of HONO or the precipitation of fresh snow with higher $\mathrm{NO}_{2}{ }^{-}$concentrations due to the scavenging of gas phase $\mathrm{HONO}$. The destruction of $\mathrm{NO}_{2}^{-}$ is dominated by the reaction with $\mathrm{OH}(\mathrm{R} 1)$, while the photolysis is a negligible sink of $\mathrm{NO}_{2}{ }^{-}$under natural conditions. This

Table 3

Calculated QLL concentrations and gas phase $\mathrm{NO}_{x}$ production rates calculated for conditions at Summit observed in the summer of 2000

\begin{tabular}{lllllll}
\hline Time $^{\mathrm{a}}(\mathrm{h})$ & {$\left[\mathrm{NO}_{3}^{-}\right](\mathrm{M})$} & $\begin{array}{l}{\left[\mathrm{NO}_{2}^{-}\right]} \\
\left(\times 10^{-9} \mathrm{M}\right)\end{array}$ & $\begin{array}{l}{\left[\mathrm{NO}_{2}\right]} \\
\left(\times 10^{-8} \mathrm{M}\right)\end{array}$ & $\begin{array}{l}{[\mathrm{NO}]} \\
\left(\times 10^{-12} \mathrm{M}\right)\end{array}$ & $\begin{array}{l}{[\mathrm{OH}]} \\
\left(\times 10^{-9} \mathrm{M}\right)\end{array}$ & $\begin{array}{l}P\left(\mathrm{NO}_{2}\right)^{\mathrm{b}} \\
\left(\times 10^{12} \mathrm{molecules} \mathrm{s}^{-1}\right)\end{array}$ \\
\hline 2 & 0.229 & 5.84 & 1.59 & 1.48 & 1.38 & 1.80 \\
4 & 0.228 & 5.81 & 1.58 & 1.47 & 1.38 & 9.83 \\
$\left(\times 10^{8} \mathrm{molecules} \mathrm{s}^{-1}\right)$
\end{tabular}

a Time after the initiation of the calculations.

b Production rates of gas phase $\mathrm{NO}_{2}$ and $\mathrm{NO}$ calculated for $1 \mathrm{~L}$ of irradiated snow. 


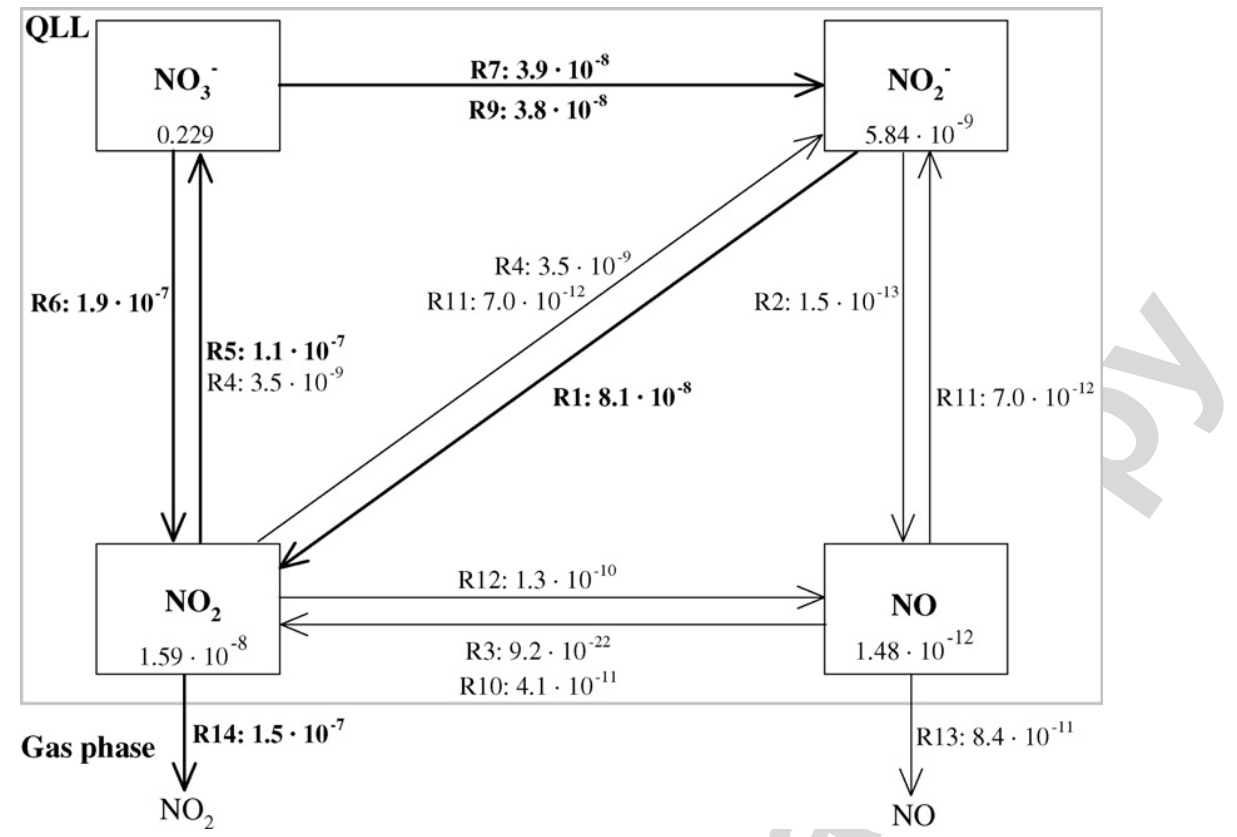

Fig. 5. Concentration and flux diagram for the photolysis of $\mathrm{NO}_{3}{ }^{-}$in the QLL of the surface snow calculated for typical conditions at Summit in the year 2000. The numbers are computed for $t=2 \mathrm{~h}$ after the initiation of the calculations. Concentrations are given in M, fluxes for single reactions (see Table 2 for reaction numbers) are given in $\mathrm{M} \mathrm{s}^{-1}$. For example, the flux of $\mathrm{NO}_{2}$ to the gas phase of $1.5 \times 10^{-7} \mathrm{M} \mathrm{s}^{-1}$ corresponds to an emission rate of $1.8 \times 10^{12}$ molecules s${ }^{-1}$ for $1 \mathrm{~L}$ of snow (see Table 3). Thick arrows represent dominant conversion pathways with fluxes larger than $3 \times 10^{-8} \mathrm{M} \mathrm{s}^{-1}$.

is in agreement with previous laboratory studies of the $\mathrm{NO}_{3}{ }^{-}$ photolysis in the presence of radical scavengers. For example, Honrath et al. [18] observed a much smaller $\mathrm{NO}_{2}$ production in the presence of OH scavengers. Similarly, Dubowski et al. [20] reported increased yields of $\mathrm{NO}_{2}{ }^{-}$if they added an $\mathrm{OH}$ radical scavenger like formate to their ice samples. Both observations indicate that the conversion of $\mathrm{NO}_{2}{ }^{-}$to $\mathrm{NO}_{2}$ ceased if $\mathrm{OH}$ were significantly removed.

The model results demonstrate that the release of $\mathrm{NO}_{x}$ is dominated by $\mathrm{NO}_{2}$ (Fig. 5). $\mathrm{NO}_{2}$ is generated either directly by the photolysis of $\mathrm{NO}_{3}{ }^{-}$(R6) or via the formation of $\mathrm{NO}_{2}{ }^{-}$ from $\mathrm{NO}_{3}{ }^{-}$by the reactions (R7) and (R9) and the subsequent reaction of $\mathrm{NO}_{2}{ }^{-}$with $\mathrm{OH}(\mathrm{R} 1)$. The main sinks of $\mathrm{NO}_{2}$ are the oxidation to $\mathrm{NO}_{3}{ }^{-}$by the $\mathrm{OH}$ radical (R5) and the transfer to the gas phase (R14). Since both pathways are almost equal, a significant fraction of the $\mathrm{NO}_{2}$ produced in the QLL undergoes chemical reactions prior to the release to the gas phase. This was also observed in previous laboratory experiments using thin ice films $[25,26]$. However, our model calculations indicate that for natural conditions the reaction with the $\mathrm{OH}$ radical (R5) is far more important than the hydrolysis of the $\mathrm{NO}_{2}$ dimer (R4) as suggested for the laboratory experiments [25].

Compared to $\mathrm{NO}_{2}$, NO concentrations as well as the NO transfer to the gas phase are orders of magnitude smaller. Therefore, NO in the QLL plays probably a negligible role for the photochemical transformation of nitrogen containing compounds as well as the release of $\mathrm{NO}_{x}$ to the firn air. The ratio of the $\mathrm{NO}_{2}$ to NO fluxes to the gas phase assumes a value of approximately 1800 (Table 3) and remains constant for several hours in the simulations.
Similarly, previous studies of the $\mathrm{NO}_{3}{ }^{-}$photolysis using natural or artificial snow samples $[3,5,18,21]$ or thin ice layers $[23,26]$ have also indicated that the $\mathrm{NO}_{x}$ flux to the gas phase was dominated by $\mathrm{NO}_{2}$, although in most cases the emission of $\mathrm{NO}$ was not negligible with ratios of the $\mathrm{NO}_{2}$ to $\mathrm{NO}$ production rates between 2 and 8 in the snow experiments $[5,18,21]$ and ratios between 10 and 23 in the experiments with the ice films $[23,26]$. However, the formation of NO possibly indicates further reactions in the gas phase like the photolysis of $\mathrm{NO}_{2}$ and HONO, which can also lead to the formation of NO. At least in the snow experiments with long residence times of the sampled air in the illuminated zone on the order of minutes [5,18,21], these gas phase reactions must be considered as discussed by Cotter et al. [21].

The calculated $\mathrm{NO}_{2}$ production rate amounts to $1.8 \times$ $10^{12}$ molecules s $^{-1}$ in $1 \mathrm{~L}$ of irradiated snow. Such a production rate translates into a $\mathrm{NO}_{2}$ flux of $5.4 \times 10^{12}$ molecules $\mathrm{m}^{-2} \mathrm{~s}^{-1}$ taking into account a snow layer with a depth of $1 \mathrm{~cm}$ and a density of $0.3 \mathrm{~g} \mathrm{~cm}^{-3}$. This flux must be considered as representative for conditions at noon due to the selected photolysis rates for the model run. We can compare this value to $\mathrm{NO}_{x}$ fluxes measured above the snow surface at Summit in 2000. According to Honrath et al. [11], the $\mathrm{NO}_{x}$ emissions were correlated with the solar radiation intensities with two thirds of the $\mathrm{NO}_{x}$ fluxes observed around noon falling in a range between 2 and $11 \times 10^{12}$ molecules $\mathrm{m}^{-2} \mathrm{~s}^{-1}$ [11]. The agreement between the modeled and observed $\mathrm{NO}_{x}$ fluxes is excellent if we assume that the $\mathrm{NO}_{x}$ release to the atmosphere is determined by the top 1 or $2 \mathrm{~cm}$ of the snow. However, it is very likely that a thicker snow layer contributes to the photochemical production of $\mathrm{NO}_{x}$ 
since the penetration depth of the solar radiation into the snow is deeper than just a few centimeters. For example, in the UV and visible range Peterson et al. [59] found that in the same snowpack at Summit approximately $10 \%$ of the incident radiation at the snow surface is transmitted to a depth of $10 \mathrm{~cm}$. Since the $\mathrm{NO}_{x}$ fluxes were measured above the snow surface, they represent only the fraction of $\mathrm{NO}_{x}$, which actually escaped from the so-called firn air, which is the interstitial air of the surface snow. The $\mathrm{NO}_{x}$ production rates in the snow can be significantly higher if a large fraction is oxidized in the firn air and re-deposited to the snow before it is released to the atmosphere. An indication of high $\mathrm{NO}_{x}$ production rates is for example the extremely high $\mathrm{NO}_{x}$ concentration in the firn air also measured at Summit [14].

The modification of the reaction mechanism developed for the laboratory experiments to conditions in the natural snowpack is accompanied by rather high uncertainties. These mainly arise from the vastly different emission spectrum of the lamp compared to the spectrum of the solar radiation [27]. The irradiation emitted by the lamp shows a strong band in the UV range, which overlaps with the absorption spectrum of $\mathrm{NO}_{3}{ }^{-}$. However, such a band is absent in the solar radiation. Therefore, the ratio of the photolysis rates of $\mathrm{NO}_{2}{ }^{-}$and $\mathrm{NO}_{3}{ }^{-}$is probably larger in the natural snowpack compared to the laboratory experiments. To account for this effect, we performed additional model runs with fixed $\mathrm{NO}_{3}{ }^{-}$photolysis rates $k_{\mathrm{R} 6}$ and $k_{\mathrm{R} 7}$ determined by the rates measured at Summit as described above, but with a $\mathrm{NO}_{2}{ }^{-}$photolysis rate $\mathrm{k}_{\mathrm{R} 2}$ increased by a factor of 10 and 100, respectively. In both cases the effects on the calculated QLL concentrations are small. The largest effects are obtained for the modeled NO concentrations, which increase by less than $1 \%$ with $k_{\mathrm{R} 2}$ multiplied by 10 and by less than $11 \%$ with $k_{\mathrm{R} 2}$ multiplied by 100 . The changes of all other concentrations are smaller than $1 \%$. The reason for these small changes is the minor importance of the $\mathrm{NO}_{2}{ }^{-}$photolysis (R2) as displayed in Fig. 5. The production rate of NO by this reaction is almost three orders of magnitude smaller than by the photolysis of $\mathrm{NO}_{2}$ (R12). Therefore, multiplying $k_{\mathrm{R} 2}$ by a factor of 100 increases the total NO production rate only by a few percent. Such a small increase in the NO production has only a slight impact on the modeled $\mathrm{NO}$ concentrations and the ratio of the $\mathrm{NO}$ and $\mathrm{NO}_{2}$ concentrations. Although additional experiments are needed to determine the exact photolysis rate constants for natural conditions, we do not expect drastic changes for instance in the ratio of the $\mathrm{NO}_{2}$ to $\mathrm{NO}$ concentrations and fluxes to the gas phase.

\subsection{HONO production in the surface snowpack}

Besides the emission of $\mathrm{NO}_{x}$, upward fluxes of HONO from the surface snow to the atmosphere have been reported for the Canadian Arctic [8] and Summit [11]. Although the gas phase HONO production is currently not incorporated into the mechanism, we can use the computed concentrations to determine if a sufficiently high production of HONO can occur in the QLL to explain the measured emissions. The HONO transfer to the gas phase depends on several parameters like the $\mathrm{NO}_{2}{ }^{-}$concentration in the QLL, the $\mathrm{pH}$ of the QLL, and the HONO phase transfer rate. Since we did not attempt to compute the proton concentrations directly, we will compare the ratio of the gas phase $\mathrm{HONO}$ to $\mathrm{NO}_{2}$ production rates and discuss the impact of the $\mathrm{pH}$ on this ratio.

HONO is a moderately weak acid with a dissociation constant $\mathrm{p} K_{\mathrm{a}}$ reported in the literature in the range from 2.3 to 5.2 [60]. Here, we use an extrapolated $\mathrm{p} K_{\mathrm{a}}$ of 3.7 at a temperature of $-20{ }^{\circ} \mathrm{C}$ [47]. Thus, $99 \%$ of the $\mathrm{NO}_{2}{ }^{-}$would be present at $\mathrm{HONO}$ in the QLL at a $\mathrm{pH}$ of 1.7. However, Table 3 demonstrates that the $\mathrm{NO}_{2}{ }^{-}$concentrations are always lower than the $\mathrm{NO}_{2}$ concentrations by a factor of approximately 3 . Even with a full conversion of $\mathrm{NO}_{2}{ }^{-}$to $\mathrm{HONO}$ at low $\mathrm{pH}$ values, the HONO concentrations will remain smaller than the $\mathrm{NO}_{2}$ concentrations in the QLL. Nevertheless, the HONO flux to the gas phase could be comparable to the $\mathrm{NO}_{2}$ flux if the lower concentration is compensated by a higher transfer rate. Similarly to the case of $\mathrm{NO}$ and $\mathrm{NO}_{2}$, we calculate the phase transfer rate relative to the Henry's law constant. Due to the much higher solubility of HONO, the Henry's law constant is significantly higher compared to the values for the nitrogen oxides. Using temperature-dependent parameters [48], we obtain a value of $930 \mathrm{M} \mathrm{atm}^{-1}$ extrapolated to $-20^{\circ} \mathrm{C}$ for HONO. Since this number is a factor of $3.6 \times 10^{4}$ higher than the Henry's law constant of $\mathrm{NO}_{2}$ at the same temperature, we assume that the phase transfer rate of HONO is significantly smaller compared to the transfer of $\mathrm{NO}_{2}$. In combination with the lower transfer rate, we conclude that the HONO transfer from the QLL is orders of magnitude smaller than the parallel $\mathrm{NO}_{x}$ transfer. Thus, the $\mathrm{NO}_{3}{ }^{-}$photolysis in snow is a negligible direct source of HONO in contrast to previous suggestions (e.g. [37]). However, such small HONO production rates can explain neither the enhanced HONO concentrations measured in the firn air [14], nor the HONO emissions observed above the snowpack $[8,11]$. We suggest that HONO is produced in the firn air either by gas phase reactions (e.g. $\mathrm{NO}+\mathrm{OH}$ ) or by heterogeneous reactions of $\mathrm{NO}_{2}$ or $\mathrm{HO}_{2} \mathrm{NO}_{2}$ at the snow crystal surfaces. Several studies have demonstrated that the heterogeneous hydrolysis of $\mathrm{NO}_{2}$ yields gas phase HONO (e.g. [61]). More recently, George et al. [62] demonstrated that HONO was produced with a high efficiency by the heterogeneous reaction of $\mathrm{NO}_{2}$ with light absorbing organic compounds. Since Grannas et al. [35] reported contributions of phenols and further aromatic compounds to the organic content of snow samples collected at Summit, the suggested mechanism might contribute to the HONO formation in the firn air. However, whether the firn air concentrations of $\mathrm{NO}_{x}, \mathrm{OH}$, and $\mathrm{HO}_{2} \mathrm{NO}_{2}$ are high enough to produce significant amounts of HONO remains unresolved as discussed by Cotter et al. [21].

It has been proposed that the HONO flux out of or into the snowpack depends on the $\mathrm{pH}$ value of the snow [17,36]. Our model calculations indicate that the $\mathrm{pH}$ value of the QLL does not impact the formation rate of HONO in the snow: the formation is always negligible due to the small $\mathrm{NO}_{2}{ }^{-}$concentrations obtained in the model calculations. However, the $\mathrm{pH}$ can obviously determine if the HONO produced in the firn air is absorbed by the QLL or rather released to the atmosphere above the snowpack. While $\mathrm{pH}$ values can enhance the dissociation of HONO into $\mathrm{H}^{+}$and $\mathrm{NO}_{2}{ }^{-}$, thus increasing the solubility of HONO in the QLL, this effect should be most obvious at $\mathrm{pH}$ values around 
the $\mathrm{p} K_{\mathrm{s}}$ of HONO. Varying the $\mathrm{pH}$ around the $\mathrm{p} K_{\mathrm{s}}$ by \pm 1 means that either $90 \%$ or $10 \%$ of the HONO would be present in the not-dissociated form in the QLL. The measured snow $\mathrm{pH}$ represents an equilibrium value obtained from the melted snow sample. In other words, this is the $\mathrm{pH}$ of a solution containing all the electrolytes present in the snow sample. Recent laboratory experiments clearly demonstrated that the $\mathrm{pH}$ of the QLL can be significantly different compared to the melted ice [63]. At present it is not clear how the measured snow $\mathrm{pH}$ relates to the $\mathrm{pH}$ of the QLL. Further studies on natural snow samples are needed to investigate this value since it is the crucial parameter for the air-snow equilibrium of acidic and alkaline species.

Due to the small volume of the QLL, it still constitutes only a limited reservoir for HONO. However, as shown in Fig. 5, $\mathrm{NO}_{2}{ }^{-}$is unstable in the QLL, where it is destroyed with a rate of $9.5 \times 10^{11}$ molecules $\mathrm{L}_{\text {snow }}^{-1} \mathrm{~s}^{-1}$ for typical conditions at Summit. We can compare this destruction rate with observed deposition fluxes of HONO to snow surfaces. For example, a HONO flux of up to $120 \mathrm{nmol} \mathrm{m}^{-2} \mathrm{~h}^{-1}$ was observed in the Apennine mountains in Italy in spring [36]. This value corresponds to a HONO flux of $2.0 \times 10^{13}$ molecules $\mathrm{m}^{-2} \mathrm{~s}^{-1}$. If we assume a typical snow density of $0.3 \mathrm{~g} \mathrm{~cm}^{-3}$, the photochemical destruction in a snow layer with a depth of $7 \mathrm{~cm}$ is sufficient to destroy the deposited HONO completely. The conditions of the surface snow at Summit are probably significantly different compared to the springtime snow in the Apennines regarding the snow composition and temperature, the solar radiation intensities, and the $\mathrm{pH}$ of the snow. Nevertheless, the comparison indicates that the proposed photochemical mechanism for the surface snow is well able to explain the fate of the HONO deposited to the snow surface.

\section{Summary and conclusions}

We developed a comprehensive mechanism for the photochemical transformation of $\mathrm{NO}_{3}{ }^{-}$to $\mathrm{NO}_{2}{ }^{-}$in snow and further to more volatile nitrogen containing compounds like $\mathrm{NO}$ and $\mathrm{NO}_{2}$. Applying this mechanism to data obtained in different laboratory experiments, we adjusted unknown photolysis rates of $\mathrm{NO}_{3}{ }^{-}$and $\mathrm{NO}_{2}{ }^{-}$in artificial snow for the experimental conditions. The rates were further verified using previously published laboratory experiments and field studies. These comparisons demonstrate that (i) the general mechanism is able to capture the main features of the photochemical transformation of nitrogen compounds in snow and (ii) the adjusted rates can be applied to a wide range of conditions.

We adjusted the photochemical mechanism to typical summer conditions for the Greenland ice sheet. These simulations showed that the $\mathrm{NO}_{2}{ }^{-}$concentrations in the snow remained extremely low. $\mathrm{NO}_{2}{ }^{-}$remains still an important intermediate for the formation of $\mathrm{NO}_{2}$ in the snow although the $\mathrm{NO}_{2}$ formation is dominated by the photolysis of $\mathrm{NO}_{3}{ }^{-}$. A large fraction of the produced $\mathrm{NO}_{2}$ is oxidized back to $\mathrm{NO}_{3}{ }^{-}$reducing the net $\mathrm{NO}_{3}{ }^{-}$destruction rate by $40 \%$. The model calculations indicate that for summer conditions in Greenland, out of five $\mathrm{NO}_{3}{ }^{-}$ molecules initially photolyzed in the snow, approximately three are released to the firn air in the form of $\mathrm{NO}_{2}$ and two molecules are re-oxidized back to $\mathrm{NO}_{3}{ }^{-}$. Comparisons of the modeled $\mathrm{NO}_{2}{ }^{-}$and $\mathrm{NO}_{2}$ concentrations and the Henry's law constants of $\mathrm{HONO}$ and $\mathrm{NO}_{2}$ further indicate that the $\mathrm{HONO}$ production within the snow is probably negligible. We suggest that HONO, which is readily emitted by the sun-lit snowpack, is formed in the firn air possibly by the heterogeneous reaction of $\mathrm{NO}_{2}$ on the surface of the ice crystals.

The simulations with the photochemical mechanism further show that observed $\mathrm{NO}_{x}$ emissions are easily reconciled by the calculated $\mathrm{NO}_{2}$ production in several centimeters of the surface snow. In addition, HONO deposition fluxes as observed onto more alkaline snow surfaces in lower latitudes are also in good agreement with the destruction rates for $\mathrm{NO}_{2}{ }^{-}$obtained with the model. In summary, we conclude that the proposed photochemical mechanism for the transformation of $\mathrm{NO}_{3}{ }^{-}$in snow represents a reasonable representation for the processes occurring in natural snow surfaces.

Nevertheless, further laboratory and field studies are needed to improve the mechanism and extend its applicability since several uncertainties remain. Although the mechanism is limited to nitrogen-containing compounds, the important role of other reactive species like the $\mathrm{OH}$ radical becomes already obvious. In agreement with previous experiments in the presence of radical scavengers $[18,20]$, the model indicates that the reactions with $\mathrm{OH}$ radicals constitute important sinks for $\mathrm{NO}_{2}{ }^{-}$as well as for $\mathrm{NO}_{2}$ (Fig. 5). Chu and Anastasio [64] concluded that the most important $\mathrm{OH}$ source in the snow is from the photolysis of $\mathrm{H}_{2} \mathrm{O}_{2}$, which is omnipresent in natural snow. This shows that the recommended photochemical mechanism cannot account for all processes known to occur in the natural snowpack. Besides the sources of $\mathrm{OH}$ radicals, this concerns also the processing of organic compounds in the snow. Further studies are needed to develop a full photochemical reaction mechanism for the snow.

Additional uncertainties arise from the limited knowledge of the properties of the QLL. Furthermore, less reactive impurities like sea-salt components may increase the liquid fraction and, thus, reduce the QLL concentrations of the reactive compounds. Further laboratory and modeling studies are needed to characterize the QLL so that it can be represented better in the model.

\section{Acknowledgement}

Financial support by the Deutsche Forschungsgemeinschaft (DFG) is gratefully acknowledged.

\section{References}

[1] F. Dominé, P.B. Shepson, Air-snow interactions and atmospheric chemistry, Science 297 (2002) 1506-1510.

[2] R.E. Honrath, M.C. Peterson, S. Guo, J.E. Dibb, P.B. Shepson, B. Campbell, Evidence of $\mathrm{NO}_{x}$ production within or upon ice particles in the Greenland snowpack, Geophys. Res. Lett. 26 (1999) 695-698.

[3] R.E. Honrath, M.C. Peterson, M.P. Dziobak, J.E. Dibb, M.A. Arsenault, S.A. Green, Release of $\mathrm{NO}_{x}$ from sunlight-irradiated midlatitude snow, Geophys. Res. Lett. 27 (2000) 2237-2240.

[4] B. Ridley, J. Walega, D. Montzka, F. Grahek, E. Atlas, F. Flocke, V. Stroud, J. Deary, A. Gallant, H. Boudries, J. Bottenheim, K. Anlauf, D. Worthy, 
A.L. Sumner, B. Splawn, P. Shepson, Is the Arctic surface layer a source and sink of $\mathrm{NO}_{x}$ in winter/spring? J Atmos. Chem. 36 (2000) 1-22.

[5] A.E. Jones, R. Weller, E.W. Wolff, H.-W. Jacobi, Speciation and rate of photochemical $\mathrm{NO}$ and $\mathrm{NO}_{2}$ production in Antarctic snow, Geophys. Res. Lett. 27 (2000) 345-348.

[6] A.E. Jones, R. Weller, P.S. Anderson, H.-W. Jacobi, E.W. Wolff, O. Schrems, H. Miller, Measurements of $\mathrm{NO}_{x}$ emissions from the Antarctic snowpack, Geophys. Res. Lett. 28 (2001) 1499-1502.

[7] D. Davis, J.B. Nowak, G. Chen, M. Buhr, R. Arimoto, A. Hogan, F. Eisele, L. Mauldin, D. Tanner, R. Shetter, B. Lefer, P. McMurry, Unexpected high levels of NO observed at South Pole, Geophys. Res. Lett. 28 (2001) 3625-3628.

[8] X. Zhou, H.J. Beine, R.E. Honrath, J.D. Fuentes, W. Simpson, P.B. Shepson, J.W. Bottenheim, Snowpack photochemical production of HONO: a major source of $\mathrm{OH}$ in the arctic boundary layer in springtime, Geophys. Res. Lett. 28 (2001) 4087-4090.

[9] J.E. Dibb, M. Arsenault, M.C. Peterson, R.E. Honrath, Fast nitrogen oxide photochemistry in Summit, Greenland snow, Atmos. Environ. 36 (2002) 2501-2511.

[10] R. Qiu, S.A. Green, R.E. Honrath, M.C. Peterson, Y. Lu, M. Dziobak, Measurements of $J_{\mathrm{NO}_{3}}$ - in snow by nitrate-based actinometry, Atmos. Environ. 36 (2002) 2563-2571.

[11] R.E. Honrath, Y. Lu, M.C. Peterson, J.E. Dibb, M.A. Arsenault, N.J. Cullen, K. Steffen, Vertical fluxes of $\mathrm{NO}_{x}, \mathrm{HONO}$, and $\mathrm{HNO}_{3}$ above the snowpack at Summit, Greenland, Atmos. Environ. 36 (2002) 26292640.

[12] H.J. Beine, R.E. Honrath, F. Dominé, W.R. Simpson, J.D. Fuentes, $\mathrm{NO}_{x}$ during background and ozone depletion periods at Alert: fluxes above the snow surface, J. Geophys. Res. 107 (D21) (2002) 4584, doi:10.1029/2002JD002082.

[13] H.J. Beine, F. Dominé, A. Ianniello, M. Nardino, I. Allegrini, K. Teinilä, R. Hillamo, Fluxes of nitrate between snow surfaces and the atmosphere in the European high Arctic, Atmos. Chem. Phys. 3 (2003) 335346.

[14] H.-W. Jacobi, R.C. Bales, R.E. Honrath, M.C. Peterson, J.E. Dibb, A.L. Swanson, M.R. Albert, Reactive trace gases measured in the interstitial air of surface snow at Summit, Greenland, Atmos. Environ. 38 (2004) 1687-1697.

[15] D. Davis, G. Chen, M. Buhr, J. Crawford, D. Lenschow, B. Lefer, R. Shetter, F. Eisele, L. Mauldin, A. Hogan, South Pole $\mathrm{NO}_{x}$ chemistry: an assessment of factors controlling variability and absolute levels, Atmos. Environ. 38 (2004) 5375-5388

[16] J.E. Dibb, L.G. Huey, D.L. Slusher, D.J. Tanner, Soluble reactive nitrogen oxides at South Pole during ISCAT 2000, Atmos. Environ. 38 (2004) 5399-5409.

[17] A. Amoroso, H.J. Beine, R. Sparapani, M. Nardino, I. Allegrini, Observation of coinciding arctic boundary layer ozone depletion and snow surface emissions of nitrous acid, Atmos. Environ. 40 (2006) 1949-1956.

[18] R.E. Honrath, S. Guo, M.C. Peterson, M.P. Dziobak, J.E. Dibb, M.A. Arsenault, Photochemical production of gas phase $\mathrm{NO}_{x}$ from ice crystal $\mathrm{NO}_{3}{ }^{-}$, J. Geophys. Res. 105 (2000) 24183-24190.

[19] Y. Dubowski, A.J. Colussi, M.R. Hoffmann, Nitrogen dioxide release in the $302 \mathrm{~nm}$ band photolysis of spray-frozen aqueous nitrate solutions. Atmospheric implications, J. Phys. Chem. A 105 (2001) 4928-4932.

[20] Y. Dubowski, A.J. Colussi, C. Boxe, M.R. Hoffmann, Monotonic increase of nitrite yields in the photolysis of nitrate in ice and water between 238 and 294 K, J. Phys. Chem. A 106 (2002) 6967-6971.

[21] E.S.N. Cotter, A.E. Jones, E.W. Wolff, S.J.-B. Baugitte, What controls photochemical $\mathrm{NO}$ and $\mathrm{NO}_{2}$ production from Antarctic snow? Laboratory investigation assessing the wavelength and temperature dependence, J. Geophys. Res. 108 (D4) (2003) 4147, doi:10.1029/2002JD002602.

[22] L. Chu, C. Anastasio, Quantum yields of hydroxyl radical and nitrogen dioxide from the photolysis of nitrate on ice, J. Phys. Chem. A 107 (2003) 9594-9602.

[23] C.S. Boxe, A.J. Colussi, M.R. Hoffmann, D. Tan, J. Mastromarino, A.T. Case, S.T. Sandholm, D.D. Davis, Multiscale ice fluidity in $\mathrm{NO}_{x}$ photodesorption from frozen nitrate solutions, J. Phys. Chem. A 107 (2003) 11409-11413.
[24] T. Blunier, G.L. Floch, H.-W. Jacobi, E. Quansah, Isotopic view on nitrate loss in Antarctic surface snow, Geophys. Res. Lett. 32 (2005) L13501.

[25] C.S. Boxe, A.J. Colussi, M.R. Hoffmann, J.G. Murphy, P.J. Wooldridge, T.H. Bertram, R.C. Cohen, Photochemical production and release of gaseous $\mathrm{NO}_{2}$ from nitrate-doped water ice, J. Phys. Chem. A 109 (2005) 8520-8525.

[26] C.S. Boxe, A.J. Colussi, M.R. Hoffmann, I.M. Perez, J.G. Murphy, R.C. Cohen, Kinetics of $\mathrm{NO}$ and $\mathrm{NO}_{2}$ evolution from illuminated frozen nitrate solutions, J. Phys. Chem. A 110 (2006) 3578-3583.

[27] H.-W. Jacobi, T. Annor, E. Quansah, Investigation of the photochemical decomposition of nitrate, hydrogen peroxide, and formaldehyde in artificial snow, J. Photochem. Photobiol. A 179 (2006) 330-338.

[28] G. Chen, D. Davis, J. Crawford, L.M. Hutterli, L.G. Huey, D. Slusher, L. Mauldin, F. Eisele, D. Tanner, J. Dibb, M. Buhr, J. McConnell, B. Lefer, R. Shetter, D. Blake, C.H. Song, K. Lombardi, J. Arnoldy, A reassessment of $\mathrm{HO}_{x}$ South Pole chemistry based on observations recorded during ISCAT 2000, Atmos. Environ. 38 (2004) 54515461.

[29] J. Yang, R.E. Honrath, M.C. Peterson, J.E. Dibb, A.L. Sumner, P.B. Shepson, M. Frey, H.-W. Jacobi, A. Swanson, N. Blake, Impacts of snowpack emissions on deduced levels of $\mathrm{OH}$ and peroxy radicals at Summit, Greenland, Atmos. Environ. 36 (2002) 2523-2534.

[30] M. Legrand, P. Mayewski, Glaciochemistry of polar ice cores: a review, Rev. Geophys. 35 (1997) 219-243.

[31] R. Röthlisberger, M.A. Hutterli, E.W. Wolff, R. Mulvaney, H. Fischer, M. Bigler, K. Goto-Azuma, M.E. Hansson, U. Ruth, M.-L. SiggaardAndersen, J.P. Steffensen, Nitrate in Greenland and Antarctic ice cores: a detailed description of post-depositional processes, Ann. Glaciol. 35 (2002) 209-216.

[32] J.R. McCabe, C.S. Boxe, A.J. Colussi, M.R. Hoffmann, M.H. Thiemens, Oxygen isotopic fractionation in the photochemistry of nitrate in water and ice, J. Geophys. Res. 110 (2005) D15310, doi:10.1029/2004JD005484.

[33] J. Mack, J.R. Bolton, Photochemistry of nitrite and nitrate in aqueous solution: a review, J. Photochem. Photobiol. A 128 (1999) 1-13.

[34] A.L. Sumner, P.B. Shepson, Snowpack production of formaldehyde and its effect on the Arctic troposphere, Nature 398 (1999) 230-233.

[35] A.M. Grannas, P.B. Shepson, T.R. Filley, Photochemistry and nature of organic matter in Arctic and Antarctic snow, Global Biogeochem. Cycles 18 (GB1006) (2004), doi:10.1029/2003GB002133.

[36] H.J. Beine, A. Amoroso, G. Esposito, R. Sparapani, A. Ianniello, T. Georgiadis, M. Nardino, P. Bonasoni, P. Cristofanelli, F. Dominé, Deposition of atmospheric nitrous acid on alkaline snow surfaces, Geophys. Res. Lett. 32 (2005) L10808, doi:10.1029/2005GL022589.

[37] K.C. Clemitshaw, Coupling between the tropospheric photochemistry of nitrous acid (HONO) and nitric acid $\left(\mathrm{HNO}_{3}\right)$, Environ. Chem. 3 (2006) $31-34$.

[38] W. Liao, A.T. Case, J. Mastromarino, D. Tan, J.E. Dibb, Observations of HONO by laser-induced fluorescence at the South Pole during ANTCI 2003, Geophys. Res. Lett. 33 (2006) L09810, doi:10.1029/2005GL025470.

[39] H.-W. Jacobi, B. Kwakye-Awuah, O. Schrems, Photochemical decomposition of hydrogen peroxide $\left(\mathrm{H}_{2} \mathrm{O}_{2}\right)$ and formaldehyde (HCHO) in artificial snow, Ann. Glaciol. 39 (2004) 29-33.

[40] D. Zehavi, J. Rabani, Pulse radiolytic investigation of $\mathrm{O}_{\mathrm{aq}}{ }^{-}$radical ions, J. Phys. Chem. 75 (1971) 1738-1744.

[41] G.C. Barker, P. Fowles, B. Stringer, Pulse radiolytic induced transient electrical conductance in liquid solutions. Part 2. Radiolysis of aqueous solutions of $\mathrm{NO}_{3}{ }^{-}, \mathrm{NO}_{2}{ }^{-}$and $\mathrm{Fe}(\mathrm{CN})_{6}{ }^{3-}$, Trans. Faraday Soc. 66 (1970) 1509-1519.

[42] H.H. Awad, D.M. Stanbury, Autoxidation of NO in aqueous solution, Int. J. Chem. Kinet. 25 (1993) 375-381.

[43] J.L. Cheung, Y.Q. Li, J. Boniface, Q. Shi, P. Davidovits, D.R. Worsnop, J.T. Jayne, C.E. Kolb, Heterogeneous interactions of $\mathrm{NO}_{2}$ with aqueous surfaces, J. Phys. Chem. A 104 (2000) 2655-2662.

[44] T. Løgager, K. Sehested, Formation and decay of peroxynitrous acid: a pulse radiolysis study, J. Phys. Chem. 97 (1993) 6664-6669.

[45] U.K. Kläning, K. Sehested, T. Wolff, Ozone formation in laser flash photolysis of oxoacids and oxoanions of chlorine and bromine, J. Chem. Soc., Faraday Trans. 80 (1984) 2969-2979. 
[46] H. Strehlow, I. Wagner, Flash photolysis in aqueous nitrite solutions, Z. Phys. Chem. NF 132 (1982) 151-160.

[47] J.-Y. Park, Y.-N. Lee, Solubility and decomposition kinetics of nitrous acid in aqueous solution, J. Phys. Chem. 92 (1988) 6294-6302.

[48] R. Sander, Compilation of Henry's Law Constants for Inorganic and Organic Species of Potential Importance in Environmental Chemistry, Version 3, 1999. http://dionysos.mpch-mainz.mpg.de/ sander/res/ henry.html.

[49] C. Girardet, C. Toubin, Molecular atmospheric pollutant adsorption on ice: a theoretical survey, Surf. Sci. Rep. 44 (2001) 159-238.

[50] H. Bluhm, D.F. Ogletree, C.S. Fadley, Z. Hussain, M. Salmeron, The premelting of ice studied with photoelectron spectroscopy, J. Phys. Condens. Matter 14 (2002) L227-L233.

[51] H. Cho, P.B. Shepson, L.A. Barrie, J.P. Cowin, R. Zaveri, NMR investigation of the quasi-brine layer in ice/brine mixtures, J. Phys. Chem. B 106 (2002) 11226-11232.

[52] A. Döppenschmidt, H.-J. Butt, Measuring the thickness of the liquid-like layer on ice surfaces with atomic force microscopy, Langmuir 16 (2000) 6709-6714.

[53] X. Wei, P.B. Miranda, C. Zhang, Y.R. Shen, Sum-frequency spectroscopic studies of ice interfaces, Phys. Rev. B 66 (2002) 085401.

[54] J.E. Dibb, R.W. Talbot, J.W. Munger, D.J. Jacob, S.-M. Fao, Air-snow exchange of $\mathrm{HNO}_{3}$ and $\mathrm{NO}_{y}$ at Summit, Greenland, J. Geophys. Res. 103 (1998) 3475-3486.

[55] P. Hoffmann, V.K. Karandashev, T. Sinner, H.M. Ortner, Chemical analysis of rain and snow samples from Chernogolovka/Russia by IC, TXRF and ICP-MS, Fresenius J. Anal. Chem. 357 (1997) 1142-1148.
[56] Y. Miura, H. Hamada, Ion chromatography of nitrite at the ppb level with photometric measurement of iodine formed by post-column reaction of nitrite with iodide, J. Chromatogr. A 850 (1999) 153-160.

[57] A. Fernandez-Gutierrez, C. Cruces-Blanco, S. Cortacero-Ramirez, A. Segura-Carretero, Sensitive determination of inorganic anions at trace levels in samples of snow water from Sierra Nevada (Granada, Spain) by capillary ion electrophoresis using Calix[4]arene as selective modifier, Chromatographia 52 (2000) 413-417.

[58] S.-M. Li, Particulate and snow nitrite in the spring arctic troposphere, Atmos. Environ. 27 (1993) 2959-2967.

[59] M. Peterson, D. Barber, S. Green, Monte Carlo modeling and measurements of actinic flux levels in Summit, Greenland snowpack, Atmos. Environ. 36 (2002) 2545-2551.

[60] E. Riordan, N. Minogue, D. Healy, P. O’Driscoll, J.R. Sodeau, Spectroscopic and optimization modling study of nitrous acid in aqueous solution, J. Phys. Chem. A 109 (2005) 779-786.

[61] B.J. Finlayson-Pitts, L.M. Wingen, A.L. Sumner, D. Syomin, K.A. Ramazan, The heterogeneous hydrolysis of $\mathrm{NO}_{2}$ in laboratory systems and in outdoor and indoor atmospheres: an integrated mechanism, Phys. Chem. Chem. Phys. 5 (2003) 223-242.

[62] C. George, R.S. Strekowski, J. Kleffmann, K. Stemmler, M. Ammann, Photoenhanced uptake of gaseous $\mathrm{NO}_{2}$ on solid organic compounds: a photochemical source of HONO? Faraday Disc. 130 (2005) 195-210.

[63] C. Robinson, C.S. Boxe, M.I. Guzmán, A.J. Colussi, M.R. Hoffmann, Acidity of frozen electrolyte solutions, J. Phys. Chem. B 110 (2006) 7613-7616.

[64] L. Chu, C. Anastasio, Formation of hydroxyl radical from the photolysis of frozen hydrogen peroxide, J. Phys. Chem. A 109 (2005) 6264-6271. 